\title{
The use of columns of the zeolite clinoptilolite in the remediation of aqueous nuclear waste streams
}

\author{
Alan Dyer ${ }^{1} \cdot$ Joe Hriljac $^{2} \cdot$ Nick Evans $^{3,9}$ (D) Ian Stokes ${ }^{4} \cdot$ Peter Rand $^{4} \cdot$ Simon Kellet $^{4} \cdot$ Risto Harjula $^{5} \cdot$ Teresia Moller $^{5}$. \\ Zoe Maher $^{6}$. Ross Heatlie-Branson ${ }^{6}$. Jonathan Austin ${ }^{7} \cdot$ Scott Williamson-Owens ${ }^{7} \cdot$ Manon Higgins-Bos $^{7}$. \\ Kurt Smith ${ }^{7} \cdot$ Luke O'Brien $^{7} \cdot$ Nick Smith $^{7,8} \cdot$ Nick Bryan $^{7}$
}

Received: 28 May 2018 / Published online: 22 November 2018

(c) The Author(s) 2018

\begin{abstract}
Mud Hills clinoptilolite has been used in an effluent treatment plant (SIXEP) at the Sellafield nuclear reprocessing site. This material has been used to remove ${ }^{134 / 137} \mathrm{Cs}$ and ${ }^{90} \mathrm{Sr}$ successfully from effluents for 3 decades. Samples of the zeolite have been tested in column experiments to determine their ability to remove radioactive $\mathrm{Cs}^{+}$and $\mathrm{Sr}^{2+}$ ions under increasing con-

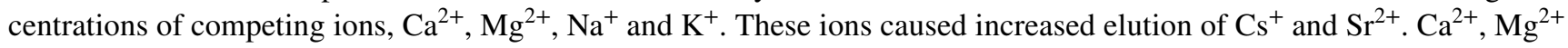
and $\mathrm{K}^{+}$were more effective competitors than $\mathrm{Na}^{+}$. For $\mathrm{Na}^{+}$, it was found that if concentration was reduced, then column performance recovered rapidly.
\end{abstract}

Keywords Ion exchange $\cdot$ Clinoptilolite $\cdot$ Caesium $\cdot$ Strontium $\cdot$ Effluent treatment

\section{Introduction}

Ion exchange provides a reliable and cost-effective method for removing radioactive $\mathrm{Cs}^{+}$and $\mathrm{Sr}^{2+}$ from liquid wastes, provided that the ionic strength is relatively low [1]. In 1984, BNFL Ltd. published details of the site ion exchange effluent plant (SIXEP) on their Sellafield site, which uses columns of the ion exchanger clinoptilolite to remediate alkaline nuclear fuel storage pond waters and other legacy high $\mathrm{pH}$

Electronic supplementary material The online version of this article (https://doi.org/10.1007/s10967-018-6329-8) contains supplementary material, which is available to authorized users.

Nick Evans

evansnic@fjfi.cvut.cz

Alan Dyer

aldilp@aol.com

1 Institute of Materials Research, University of Salford, Salford M5 4WT, UK

2 School of Chemistry, University of Birmingham, Edgbaston, Birmingham B15 2TT, UK

3 Fakulta jaderná a fyzikálně inženýrská, České vysoké učení technické v Praze, Břehová 78/7, 11519 Staré Město, Praha 1, Czech Republic

4 Sellafield, Seascale, Cumbria CA20 1PG, UK aqueous nuclear waste streams [2]. Clinoptilolite, a naturally occurring zeolite, can exchange $\mathrm{Cs}^{+}$and $\mathrm{Sr}^{2+}$ radioisotopes selectively from aqueous solutions in the presence of other common cations, particularly $\mathrm{Na}^{+}[3,4]$. For the clinoptilolite used at Sellafield, $1 \mathrm{~mol}$ of $\mathrm{Sr}^{2+}$ and $20 \mathrm{~mol}$ of $\mathrm{Cs}^{+}$may be selectively extracted in the presence of $7.5 \times 10^{5} \mathrm{~mol}$ of $\mathrm{Na}^{+}, 6.5 \times 10^{3} \mathrm{~mol}$ of $\mathrm{Mg}^{2+}$ and $5 \times 10^{3} \mathrm{~mol}$ of $\mathrm{Ca}^{2+}[5]$.

Clinoptilolite is one of the most naturally abundant zeolites [6]. It is mined commercially in at least 16 countries, so ensuring its supply. Further, as an aluminosilicate, it is compatible with encapsulation for long-term storage and subsequent disposal [7]. It can also be used in particle sizes appropriate for columns, and most clinoptilolites are stable under

5 Laboratory of Radiochemistry, University of Helsinki, Helsinki, Finland

6 National Nuclear Laboratory, Central Laboratory, Sellafield, Seascale, Cumbria CA20 1PG, UK

7 National Nuclear Laboratory, Chadwick House, Warrington Road, Birchwood Park, Warrington WA3 6AE, UK

8 School of Earth Atmospheric and Environmental Sciences, University of Manchester, Oxford Road, Manchester M13 9PL, UK

9 Department of Chemistry and Forensics, Nottingham Trent University, Erasmus Darwin Building, Clifton Campus, Nottingham NG11 8NS, UK 
the conditions encountered in nuclear effluents. During the design of the SIXEP plant, there was an extensive evaluation of a wide range of inorganic and organic cation exchange materials. The study recommended that clinoptilolite from the Calico Hills formation at Mud Hills, near Edwards Air Base in California, be selected, following comparison with other clinoptilolite from deposits in Turkey, Japan, South Africa and the USA. Ames [8] studied the performance of several natural zeolites (clinoptilolite, mordenite, chabazite, stilbite, analcite, sodalite) and a synthetic sample of Zeolite A. Although the synthetic sample showed the highest selectivity for $\mathrm{Sr}^{2+}$ over $\mathrm{Ca}^{2+}$, clinoptilolite was the best performing of the natural zeolites. Marinin and Brown [1] tested the selectivity of a range of natural and synthetic zeolite ion exchangers, ion exchange resins and composite materials. They found that in the low $\mathrm{Ca}$ concentration region $(<20 \mathrm{ppm})$, clinoptilolite showed the second highest selectivity for $\mathrm{Sr}^{2+}$ over $\mathrm{Ca}^{2+}$ (the best performing material was a synthetic carbon fibre material, impregnated with $\mathrm{MnO}_{2}$ ), even though the clinoptilolite had a relatively low $\mathrm{K}_{\mathrm{d}}$ compared to some of the other materials. Interestingly, the natural clinoptilolite showed better selectivity than synthetic zeolites. At higher $\mathrm{Ca}$ concentrations, the clinoptilolite was outperformed by other materials, but such concentrations are not observed in the feeds to SIXEP.

Clinoptilolite is one of 20 naturally occurring zeolites that have been used to extract aqueous radionuclides, and although $\mathrm{Cs}^{+}$and $\mathrm{Sr}^{2+}$ are the most commonly extracted species, $\mathrm{U}, \mathrm{Th}, \mathrm{Ra}, \mathrm{Am},{ }^{3} \mathrm{H}$ and $\mathrm{Co}$ are also extracted [5, 9]. It has been suggested that clinoptilolite could form a component of permeable reactive barriers for the remediation of $\mathrm{Cs}^{+}$and $\mathrm{Sr}^{2+}$ contaminated sites [10,11]. Valcke et al. [12, 13] have suggested the use of clinoptilolite as a soil amendment to prevent uptake by plant roots. An extensive review of the use of clinoptilolite, and other zeolites, to scavenge radioisotopes is available [14]. A further general review of zeolite ion exchange covers cation selectivity series and details of the theoretical basis of their action [5].

\section{Clinoptilolite structure and exchange sites}

The clinoptilolite used in SIXEP has an ideal formula of $\mathrm{Na}_{6} \mathrm{Al}_{6} \mathrm{Si}_{30} \mathrm{O}_{72} \cdot 24 \mathrm{H}_{2} \mathrm{O}$. This gives a theoretical cation exchange capacity (CEC) of $2.2 \mathrm{meq}$ (milli-equivalents) per gram. However, the typical effective CEC of the clinoptilolite used in SIXEP is less than this, as it has an empirical formula of $\mathrm{Na}_{2.20} \mathrm{Mg}_{0.40} \mathrm{Ca}_{0.99} \mathrm{Sr}_{0.07} \mathrm{Al}_{6} \mathrm{Si}_{30} \mathrm{O}_{72} \cdot 24 \mathrm{H}_{2} \mathrm{O}$. The SIXEP clinoptilolite contains $95 \%$ clinoptilolite, with smaller amounts of albite, barite, mica, gypsum, dolomite, $K$-feldspar, quartz, magnetite, illite and montmorillonite, which are included in the empirical formula [15]. The presence of Group II cations reduces the effective CEC, because $\mathrm{Ca}^{2+}, \mathrm{Mg}^{2+}$ and $\mathrm{Sr}^{2+}$ are not exchanged as readily as $\mathrm{Na}^{+}$.

Clinoptilolite has narrow channels with pore diameters in the range of 3.5-3.9 A, which is similar to the size of a hydrated $\mathrm{Cs}^{+}$ion [16]. This may be responsible for the high $\mathrm{Cs}^{+}$selectivity over other monovalent species. Three distinct cation binding sites are found within the clinoptilolite structure: Na1, Ca2, K3. The Na1 site has ninefold coordination, whilst the $\mathrm{Ca} 2$ and $\mathrm{K} 3$ sites are characterised by eightfold coordination [17]. Um and Papelis [17] used $\mathrm{X}$-ray absorption spectroscopy to probe the coordination environment of $\mathrm{Sr}^{2+}$ in clinoptilolite. They found that the oxygen coordination was 8-coordinate. The spectra were like those of $\mathrm{Sr}^{2+}(\mathrm{aq})$, and so they describe the $\mathrm{Sr}^{2+}$ binding as 'outer sphere', but there was a small reduction in coordination number compared to hydrated $\mathrm{Sr}^{2+}$, which could be associated with a loss of some water. The spectra were consistent with coordination by 8 oxygens at a distance of $0.26 \mathrm{~nm} \pm 0.002 \mathrm{~nm}$, which is consistent with the $\mathrm{Ca} 2$ site $(\mathrm{CN} 8,0.258 \mathrm{~nm})$. Although the $\mathrm{K} 3$ site is also eight coordinate, the bond distance is longer $(0.302 \mathrm{~nm}) . \mathrm{Ca}^{2+}$ can also occupy the Na1 site, and so Um and Papelis [17] suggested that $\mathrm{Sr}^{2+}$ might also do this, but the data suggested that occupation of this site was not significant for their sample, which could be due to the larger size of $\mathrm{Sr}^{2+}$ compared to $\mathrm{Ca}^{2+}$. O'Day et al. [18] used Extended X-ray absorption fine structure (EXAFS) spectroscopy to study the $\mathrm{Sr}^{2+}$ binding sites in heulandite samples. They found 3 distinct $\mathrm{Ca}^{2+}$ positions in the zeolite channels, each with 5 waters coordinated to each $\mathrm{Ca}$, with additional coordination by 3 oxygen atoms from the heulandite lattice. Using geometrical arguments, Palmer and Gunter [15] have suggested that $\mathrm{Ca}^{2+}, \mathrm{Mg}^{2+}$ and $\mathrm{Sr}^{2+}$ must lose part of their hydration shell to travel through the channels in the clinoptilolite structure. For $\mathrm{Sr}^{2+}$ loaded samples, the EXAFS spectra of O'Day et al. [18] were consistent with $\mathrm{Sr}^{2+}$ coordination by 8 oxygen atoms in the first shell and with two shells of $\mathrm{Al} / \mathrm{Si}$, both with approximately 2 atoms. Their data are consistent with $\mathrm{Sr}^{2+}$ occupying a Ca position in the lattice. Um and Papelis [17] determined the effect of competing cations on $\mathrm{Sr}^{2+}$ sorption, and found that ions were effective in the order $\mathrm{Ca}^{2+}>\mathrm{Mg}^{2+}>\mathrm{Na}^{+}$. They suggest that the closer charge/size match between $\mathrm{Sr}^{2+}$ and $\mathrm{Ca}^{2+}$ is the reason for the effective competitive effect of $\mathrm{Ca}$.

O'Day et al. [18] predicted that $\mathrm{Cs}^{+}$should occupy the site normally occupied by $\mathrm{K}^{+}$. Interestingly, $\mathrm{Na}^{+}$can occupy the same site as $\mathrm{Ca}^{2+}$, due to its smaller size, compared to $\mathrm{K}^{+} / \mathrm{Cs}^{+}$, and so direct exchange of $\mathrm{Sr}^{2+}$ and $\mathrm{Na}^{+}$is expected [18]. Smyth et al. [6] studied the structure of a $\mathrm{Cs}^{+}$substituted clinoptilolite by single crystal X-ray diffraction, and found that the position occupied by $\mathrm{Cs}^{+}$could not be related to any of the positions of the normal extra-framework exchangeable ions. Further, the Cs-O bonds were long 
(3.0-3.5 ̊). Interestingly, there was evidence for the loss of water from the structure upon ion exchange for $\mathrm{Cs}^{+}$. The authors suggested that there was rearrangement of cation sites in the structure rather than simple one for one cation exchange in the case of $\mathrm{Cs}^{+}$.

This paper describes column experiments and modelling work that was performed between 1978 and 2012 in support of the design and operation of the SIXEP facility at Sellafield. Despite the extensive literature describing the use of clinoptilolite in nuclear waste remediation, and related areas, there have been few studies on breakthrough curves, although some $\mathrm{Cs}^{+}$and $\mathrm{Sr}^{2+}$ data have been reported for Siberian tuffs containing 50-66\% clinoptilolite [19] and more recently Nikashina et al. [10] have presented a limited number of Sr breakthrough curves. What follows is a short description of the plant, and its role in effluent processing and the reduction of radioactive discharges to the Irish Sea. Then there is a description of the experimental and modelling programme that was used to assess and predict the performance of the ion exchange material and the plant.

The experimental programme to support SIXEP was performed in two stages. Initial work, prior to the commissioning of the plant, was performed at the Harwell UKAEA laboratories (Oxfordshire, U.K.) between 1978 and 1982. Later, an on-going experimental programme was commissioned (starting in 2004), with laboratory work taking place at the National Nuclear Laboratory (at Sellafield, U.K.), supported by Sellafield Ltd.

\section{The site ion exchange effluent plant}

SIXEP is an ion exchange plant that was designed to remove

${ }^{137} \mathrm{Cs}$ and ${ }^{90} \mathrm{Sr}$ from alkaline liquid effluent. A diagram of the SIXEP plant is shown in Fig. 1. It consists of the following units:

- Settling tanks that allow large particulates to settle from feed solutions before they are fed to the sand bed filter;

- Two sand bed filters operate in parallel to remove suspended solids to protect the ion exchange beds from blinding and to reduce the soluble $\left[\mathrm{Mg}^{2+}\right]$ in the columns. A quaternary amine polyelectrolyte flocculant is added to the solution prior to the sand bed to improve filtration performance;

- A carbonation tower, which adjusts the $\mathrm{pH}$ of the solution emerging from the sand bed from $\sim 11$ to $\sim 7$ to protect the clinoptilolite beds, which degrade at high $\mathrm{pH}$;

- Two clinoptilolite beds, which operate in series (one lead bed and one lag bed). The lead bed is replaced with fresh media when it is exhausted, and the bed that previously operated in the lag position is promoted to the lead position.

The contact time of effluent with the SIXEP clinoptilolite column is approximately $8 \mathrm{~min}$, due to the very high flow rate.

The major feeds into SIXEP are effluents from nuclear fuel storage ponds and the washings from fuel de-canning operations. Contributions also come from other parts of the Sellafield site. Pond water purges account for the bulk of the feed to SIXEP (100 s of $\mathrm{m}^{3} /$ day) and consist of demineralised water that has been dosed with $\mathrm{NaOH}$ to increase the $\mathrm{pH}$ of the pond to at least 11 . This is done to minimise the potential for corrosion of the fuel by protecting the cladding and to control the solubility of $\mathrm{Mg}$ derived from historical corrosion of Magnox cladding (a Mg/Al alloy, which when

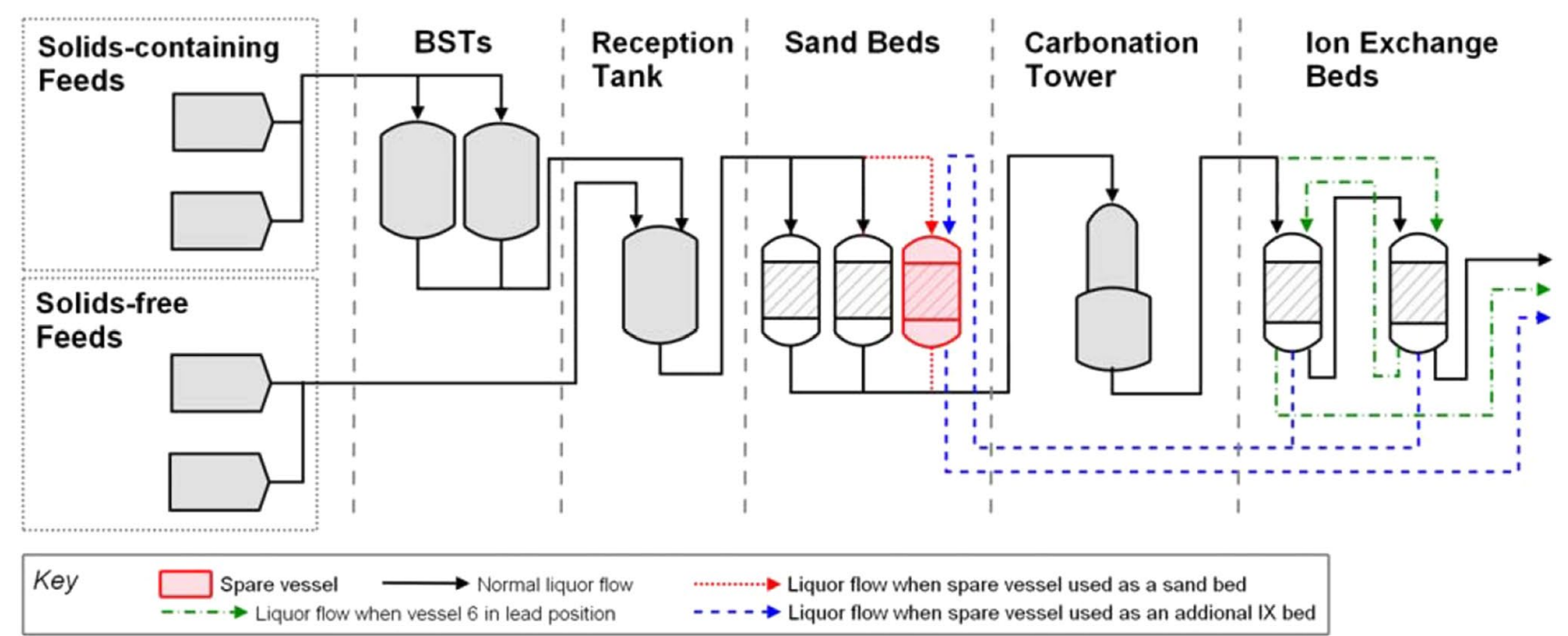

Fig. 1 Representation of the SIXEP process 
corroded forms Mg hydroxides and carbonates; [20, 21]). Some of the facilities contain stocks of corroded fuel and Magnox sludge from historical operations, and ${ }^{134 / 137} \mathrm{Cs}$ and ${ }^{90} \mathrm{Sr}$ are still released into the water from that material.

Effluent from de-canning operations, flask washing, and sand bed backwashes are routed to the bulk storage tanks (BST), where they are allowed to settle to separate most of the particulates. Water is purged from the ponds to reduce the activity within the pond and provide safe working conditions for operators. The purge is routed to the sand bed filters (via a reception tank, where it is periodically blended with feeds from the BST). The de-canner washings consist of demineralised water and fines from the fuel cladding, as well as some ${ }^{137} \mathrm{Cs}$ and ${ }^{90} \mathrm{Sr}$. On average, the BST route accounts for approximately $40 \%$ (range 10-80\%) of the radioactivity input to SIXEP, though it contributes a relatively much smaller volume.

One of the factors that govern the performance of an ion exchange material is the presence of competing ions. Clinoptilolite is very selective for $\mathrm{Cs}^{+}$and $\mathrm{Sr}^{2+}$ over $\mathrm{Na}^{+}$, which is required given the high Na concentration in the SIXEP feed solutions. Competing ions that are known to exist in appreciable concentrations in the feeds to SIXEP include:

- $\mathrm{Na}^{+}$(up to $100 \mathrm{ppm}$ ) from the $\mathrm{NaOH}$ used to maintain a high $\mathrm{pH}$;

- $\mathrm{Mg}^{2+}$ (typically $<0.6 \mathrm{ppm}$ ) that arises from dissolution of corroded Magnox nuclear fuel cladding;

- $\mathrm{Ca}^{2+}$ (typically $<1 \mathrm{ppm}$ ) that is naturally present in water supplies and may leach from sludges and concrete infrastructure;

- $\mathrm{K}^{+}$(typically $<1 \mathrm{ppm}$ ) an impurity in the $\mathrm{NaOH}$.

\section{Experimental details}

A series of $5 \mathrm{~mL}$ column experiments were performed between 1978 and 2012. The same general method was applied in these studies: a typical procedure is described below.

At the start of the experimental programme, a standard simulant feed was defined that was used throughout. It was designed to mimic the chemistry of the fuel storage pond effluents following carbonation. Table 1 shows the composition of this simulant. The simulant was spiked with $25 \mathrm{~Bq} \mathrm{~mL}-1$ of each of ${ }^{137} \mathrm{Cs}$ and ${ }^{85} \mathrm{Sr}\left({ }^{90} \mathrm{Sr}\right.$ was used in original Harwell experiments between 1978 and 1982). The laboratory column experiments were scaled down versions of the real SIXEP column.

Due to the nature of the column tests, a smaller clinoptilolite particle size was adopted $(420-500 \mu \mathrm{m})$ than that used on plant. The reduction in particle size was necessary to reduce edge effects in the columns, i.e., where the feed
Table 1 Harwell simulant composition

\begin{tabular}{lll}
\hline & ppm $\left(\mathrm{mg} \mathrm{L}^{-1}\right)$ & mmoles L $^{-1}$ \\
\hline $\mathrm{Na}$ & 100 & 4.35 \\
$\mathrm{Si}$ & 3.7 & 0.13 \\
$\mathrm{Ca}$ & 1.5 & 0.04 \\
$\mathrm{Cl}$ & 5.6 & 0.16 \\
$\mathrm{Mg}$ & 1 & 0.04 \\
$\mathrm{Cs}$ & $1.7 \times 10^{-2}$ & $1.2 \times 10^{-4}$ \\
$\mathrm{Sr}$ & $5.02 \times 10^{-4}$ & $5.72 \times 10^{-6}$ \\
\hline
\end{tabular}

flows down the walls without making proper contact with the ion exchange material. The clinoptilolite was untreated (as-received) material to match its use on plant. Batches of clinoptilolite were pre-sieved to separate the $420-500 \mu \mathrm{m}$ fraction. The sieved material was washed to remove fines and dried at $110^{\circ} \mathrm{C}$ until a constant weight was achieved. Portions were then slurried into chromatography columns $(0.9 \mathrm{~cm}$ diameter) to make up a column of $5 \mathrm{~mL}$ volume. This was repeated 5 times with different portions of sieved material, which were then dried to a constant weight to determine the average mass of material required to produce a $5 \mathrm{~mL}$ column, which was $4.70 \mathrm{~g}$.

The experimental rig consisted of feed tanks from which the simulant was pumped to the $5 \mathrm{~mL}$ columns of clinoptilolite in parallel. The active simulant was pumped through the columns using precision peristaltic pumps. A schematic diagram of the rig layout is shown in Fig. A1 (Supporting Information) and a photograph of the rig in Fig. A2 (Supporting Information).

The columns were prepared as follows: a mesh was inserted into the column (to prevent loss of clinoptilolite particulate into the effluent); $3.52 \mathrm{~g}$ of glass beads were added to the column and a further mesh added (to separate the glass from the clinoptilolite); $4.70 \mathrm{~g}$ of clinoptilolite (sieved and washed) was added and a further mesh added; sufficient glass beads were added to fill the remainder of the column. The glass beads were added to: [i] pack out the column spare space; [ii] provide a means to distribute the flow before it entered the clinoptilolite beds; and [iii] provide a tortuous path for any clinoptilolite particles (i.e. prevent loss of clinoptilolite particles into the effluent). The completed column was a well packed bed of clinoptilolite material with a standard mass (see Fig. A3 (schematic diagram) and Fig. A4 (photograph); Supporting Information).

The flow rate was that of the SIXEP design flow-sheet $\left(4200 \mathrm{~m}^{3}\right.$ day $\left.^{-1}\right)$, equivalent to a superfacial velocity of $22 \mathrm{~m}^{3} \mathrm{~m}^{-2} \mathrm{~h}^{-1}$. For the $5 \mathrm{~mL}$ columns, this is equivalent to a flow rate of approximately 20 bed volumes per hour (BV $\mathrm{hr}^{-1}$ ). Samples of the effluent from each column were taken regularly to determine the breakthrough of activity. 
Samples of effluent were taken regularly from each column. The volume of solution collected over a $1 \mathrm{~h}$ period was measured to confirm that it was being fed at the required flow rate. Effluent $\mathrm{pH}$ was in the range of $\mathrm{pH}$ 7.6-8.6. The temperature during the experiments was not controlled, because that was not feasible given the restrictions involved in the use of radioactive materials and because of the very long duration of the trials (several months). Therefore, the experiments were carried out at room temperature, with variation from day to day and overnight. The temperature in the laboratory during the experiments was typically in the range $16-22{ }^{\circ} \mathrm{C}$. The first phase experiments were also performed at room temperature, but the temperature was not recorded at the time. The variation in flow rate was $<15 \%$ (For 2nd phase experiments).

The column effluent was prepared for gamma spectrometry to determine the concentrations of ${ }^{137} \mathrm{Cs}$ and ${ }^{85} \mathrm{Sr}$. A $50 \mathrm{~mL}$ portion of the column effluent was transferred into a pre-prepared $125 \mathrm{~mL}$ vial, which contained $0.1 \mathrm{~mL}$ of $10 \mathrm{~g}$ $\mathrm{L}^{-1} \mathrm{Cs}^{+}$(as $\mathrm{CsNO}_{3}$ ), $0.1 \mathrm{~mL}$ of $10 \mathrm{~g} \mathrm{~L}^{-1} \mathrm{Sr}^{2+}$ [as $\mathrm{Sr}\left(\mathrm{NO}_{3}\right)_{2}$ ] and $0.1 \mathrm{~mL}$ of $2 \mathrm{M} \mathrm{HNO}_{3}$ as carriers to stabilise the sample (to prevent sorption of activity onto the surface of the vial). The stabilised samples were counted for $3600 \mathrm{~s}$ by gamma spectrometry as soon as possible $\left(\mathrm{E} \gamma\left({ }^{85} \mathrm{Sr}\right)=514.0 \mathrm{keV}\right.$; $\left.\mathrm{E} \gamma\left({ }^{137} \mathrm{Cs}\right)=661.7 \mathrm{keV}\right)$. Samples of the feed liquor were also collected each time a new batch was prepared to verify that it had been correctly dosed with ${ }^{85} \mathrm{Sr}$ and ${ }^{137} \mathrm{Cs}$. The gamma spectrometry system comprised of several $\mathrm{Na}$ iodide detectors. The system was calibrated using solutions of the same geometry as the effluent and feed samples, with known activities of ${ }^{85} \mathrm{Sr}$ and ${ }^{137} \mathrm{Cs}$.

\section{First phase Harwell experiments (1978-1982)}

Prior to the commissioning of SIXEP, many $5 \mathrm{~mL}$ column experiments were performed.

Many boreholes were drilled at the Mud Hills site to obtain batches of clinoptilolite (details below). A sub-sample of each batch was used in a $5 \mathrm{~mL}$ column experiment using the standard Harwell simulant (Table 1). One sample of this material was identified as a 'standard' clinoptilolite, and material from this borehole was then characterised in column experiments that used variants of the Harwell standard simulant. These included concentrations in the following ranges:

- $\mathrm{Cs}^{+}, 0.02 \mathrm{mM}-0.17 \mathrm{mM}$;

- $\mathrm{Sr}^{2+}, 0.92 \mu \mathrm{M}-9.2 \mu \mathrm{M}$

- $\mathrm{Ca}^{2+}, 0 \mathrm{mM}-0.15 \mathrm{mM}$;

- $\mathrm{Mg}^{2+}, 0.02 \mathrm{mM}-0.08 \mathrm{mM}$;

- $\mathrm{Na}^{+}, 2.17 \mathrm{mM}-8.69 \mathrm{mM}$.

\section{Second phase experiments (2007-2012)}

The second phase experiments used the same general method as that for the first phase. However, clinoptilolite from a different borehole was used. $5 \mathrm{~mL}$ column experiments were used to study the following:

- Behaviour with standard Harwell simulant.

The behaviour of $\mathrm{Cs}^{+}$and $\mathrm{Sr}^{2+}$ in standard Harwell simulant (Table 1) was determined.

- Effect of $\mathrm{K}$ concentration

Known concentrations of $\mathrm{K}^{+}$ions (as aliquots of a $5000 \mathrm{ppm} \mathrm{KCl}$ stock) were added to the standard simulant to give concentrations of 1 or 5 ppm (0.024$0.12 \mathrm{mM}$ ). In addition, experiments were performed with the Harwell simulant with no added $\mathrm{K}^{+}$.

- Effect of pulsed high Na concentrations

Triplicate column experiments were run in which the concentration of $\mathrm{Na}$ in the feed alternated between 100 and $250 \mathrm{ppm}$ (4.35 and $10.8 \mathrm{mM})$, otherwise the chemistry was that of the Harwell simulant. The Na pulsing was initiated 1 week after the trials started, i.e. after approximately $3500 \mathrm{BV}$ had been processed. The Na pulsing was conducted each week for the next 6 weeks of the trial, with the high Na simulant being fed through for 3 days per week. For the rest of the week, the standard Harwell recipe was injected. After 6 weeks, the simulant pulsing was stopped and the columns were fed with the unaltered Harwell simulant to the end of the experiment.

\section{Batch experiments}

$K$-form clinoptilolite was prepared by eluting $\mathrm{KCl}$ solution ( $2 \mathrm{M} ; 2 \mathrm{~L})$ through a column (4 g clinoptilolite). The K-form material was found to have the composition $(\mathrm{meq} / \mathrm{g}): K=1.9 ; \mathrm{Na}=0.097 ; \mathrm{Mg}=0.082 ; \mathrm{Ca}=0.030$. Batch exchange experiments were performed using the $\mathrm{K}$-form clinoptilolite by equilibrating $0.08 \mathrm{~g}$ of zeolite with $8 \mathrm{~mL}$ of $0.01 \mathrm{M}, 0.1 \mathrm{M}$ and $1 \mathrm{M}$ solutions of $\mathrm{KNO}_{3}$. The initial concentration of ${ }^{85} \mathrm{Sr}$ in the experimental solutions was approximately $700 \mathrm{~Bq} \mathrm{~mL}^{-1}$. At intervals, the samples were centrifuged ( $30 \mathrm{~min} ; 20,000 \mathrm{rpm}$ ) and filtered through a $0.22 \mu \mathrm{m}$ filter. Identical experiments were performed with the same solid:solution ratio, but in the presence of $1 \mathrm{mM}$ of bicarbonate $\left(\mathrm{KHCO}_{3}\right)$. The activities of the solutions were determined by gamma spectrometry. The equilibrium was followed by periodic sampling, and the reactions were at equilibrium after 3 weeks. At this point, the distribution coefficients $\left(K_{d}\right)$ were calculated using $(1)$ :

$K_{d}(\mathrm{ml} / \mathrm{g})=\frac{\text { concentration of radionuclide on } \operatorname{solid}(B q / \mathrm{g})}{\text { concentration of radionuclide in } \operatorname{solution}(\mathrm{Bq} / \mathrm{ml})}$ 


\section{Results and discussion}

The experimental data presented in the figures are available in the electronic supporting information. The effectiveness of the zeolite was measured by plotting the quantity of $\mathrm{Cs}^{+}$ and $\mathrm{Sr}^{2+}$ in the effluent as a percentage compared to that in the feed versus the number of bed volumes of solution treated. Interpretations of such elution curves are typically based on the selectivity that clinoptilolite shows for the cations studied, as determined from ion exchange isotherms [5], i.e.

Cs $>K>S r=B a>C a \gg N a>L i[22]$

$B a \approx S r>C a>M g[3]$

It should be noted that, according to Eisenman's Theory [23], clinoptilolite, as a high silica zeolite, should show a preference for large monovalent cations (e.g., $\mathrm{Cs}^{+}, \mathrm{K}^{+}$), rather than smaller monovalent or divalent cations. Zhao et al. [24] studied a series of synthetic clinoptilolite-like zeolites, and found that increasing the $\mathrm{Al}$ content of the material did improve uptake of divalent ions. Thus, the unusual ability of clinoptilolite to scavenge $\mathrm{Sr}$ from aqueous nuclear wastes has been an obvious bonus to the nuclear industry and has led to speculation that it exists as a speciated monovalent cation $[25,26]$, such as $\left[\mathrm{SrHCO}_{3}\right]^{+}$. This will form part of later discussions.

The interpretation of the column experiment results and the performance of SIXEP is further complicated by the very short residence time of the solutions in the columns. Ames [27] studied the kinetics of $\mathrm{Cs}^{+}$uptake by Californian clinoptilolite samples, and found that $\mathrm{Li}^{+}$substituted material gave the fastest uptake, followed by $\mathrm{Na}^{+}$and $\mathrm{K}^{+}$, with $\mathrm{Ca}^{2+}, \mathrm{Ba}^{2+}$ and $\mathrm{H}^{+}$substituted material showing slower exchange. Shahwan et al. [28] studied the uptake of $\mathrm{Cs}^{+}$by clinoptilolite. They found that the reaction was slow, taking more than 1000 min for equilibrium. The uptake was consistent with a 2 nd order kinetic model. Second order $\mathrm{Cs}^{+}$ kinetics were also observed by Cortés-Martínez et al. [16]. Shahwan et al. [28] suggested that the uptake kinetics were consistent with a relatively rapid uptake of $\mathrm{Sr}^{2+}$ to the surface of the clinoptilolite, followed by slower diffusion into the channels. Faghihian et al. [29] showed that the uptake of both $\mathrm{Cs}^{+}$and $\mathrm{Sr}^{2+}$ by natural clinoptilolite was reversible.

Palmer and Gunter [15] analysed the clinoptilolite used in SIXEP. They studied the uptake of $\mathrm{Sr}^{2+}$ in batch experiments, and found that it took 10 days for complete equilibrium to be achieved. They also tested the exchange of cations using high concentrations of $\mathrm{Sr}^{2+}$, and found that it was effective in displacing $\mathrm{Ca}^{2+}$ (98\% exchange), but that only $37 \%$ of $\mathrm{K}^{+}, 75 \%$ of $\mathrm{Na}^{+}$and $56 \%$ of $\mathrm{Mg}^{2+}$ were displaced. Similarly, Woods and Gunter [30] studied $\mathrm{Cs}^{+}$exchange in SIXEP clinoptilolite, and found that the exchange was quicker than that for $\mathrm{Sr}^{2+}$, with most exchange taking place within $10 \mathrm{~h}$, and for $\mathrm{Na}^{+}$and $\mathrm{K}^{+}$, most of the exchange was complete within $30 \mathrm{~min}$. At apparent equilibrium, there was exchange of $85 \%$ of the available $\mathrm{Na}^{+}$, compared to $50 \%$ for $\mathrm{K}^{+}, 80 \%$ for $\mathrm{Ca}^{2+}$, and $40 \%$ for $\mathrm{Mg}^{2+}$. Therefore, given the very short residence time in the columns and SIXEP (8 $\mathrm{min}$ ), the exchange reactions for $\mathrm{Cs}^{+}$and particularly $\mathrm{Sr}^{2+}$ do not approach equilibrium. As a result, the behaviour of the ions in the columns will be controlled to some extent by the relative exchange kinetics of the ions, probably at the surface of the clinoptilolite. Such initial uptake kinetics are not necessarily in the same order as that of the selectivity that is observed at equilibrium [31].

\section{First phase (Harwell) experiments}

Samples of clinoptilolite from the same borehole were selected for use in the 1978-1982 studies with a range of competing ion concentrations. These would later be used for the calibration of the plant process model. Because of the high capacity of the clinoptilolite for $\mathrm{Cs}^{+}$and $\mathrm{Sr}^{2+}$, experiments were not carried through to complete breakthrough (i.e., effluent concentration equal to feed), because of the time required, and because the real ion exchange columns in SIXEP are not operated through to complete breakthrough. Instead, the column experiments ran until an initial breakthrough was observed, which was typically by $30 \mathrm{kBV}$. Figure $2 \mathrm{a}$ shows $\mathrm{Cs}^{+}$and $\mathrm{Sr}^{2+}$ breakthrough curves for an experiment using the standard conditions (Table 1). These curves were adopted as the standard performance for SIXEP clinoptilolite, and are referred to as the 'Harwell Reference' in the text below. In the original Harwell development work in the 1970 's, minimum and target clinoptilolite performances were defined (Fig. 2a). These were arbitrary elution profiles, based on what could be realistically achieved, i.e., an ideal performance (the target) and a minimum performance that would still be viable, given the cost of disposing of spent clinoptilolite via encapsulation and eventual geological disposal. The performance of the clinoptilolite sample was within the acceptable range for both $\mathrm{Cs}^{+}$and $\mathrm{Sr}^{2+}$.

\section{Effect of $\mathrm{Cs}^{+}$and $\mathrm{Sr}^{2+}$ concentrations}

Experiments were performed with raised $\mathrm{Cs}^{+}$concentrations of $0.02,0.05$ and $0.17 \mathrm{mM}$, and $\mathrm{Sr}^{2+}$ concentrations of $0.92,2.78$ and $9.23 \mu \mathrm{M}$ (Fig. 2b, c). The increased level of $\mathrm{Cs}^{+}$in the $0.17 \mathrm{mM}$ system reduced the number of BV before Cs breakthrough occurs. The breakthrough curves produced for the 0.02 and $0.05 \mathrm{mM} \mathrm{Cs}^{+}$experiments were within the experimental reproducibility $( \pm 10 \%)$. There was a reduction of $21 \%$ from 21.5 to $15 \mathrm{kBV}$, when comparing the number of $\mathrm{BV}$ required for $10 \% \mathrm{Cs}^{+}$breakthrough in the 0.02 and $0.17 \mathrm{mM}$ experiments. All the systems with raised 
Fig. 2 Top-base case breakthrough of $\mathrm{Cs}^{+}\left(1.24 \times 10^{-7} \mathrm{M}\right)$ and $\mathrm{Sr}^{2+}$ $\left(5.56 \times 10^{-9} \mathrm{M}\right)$. Middle and bottom-effect of $\mathrm{Cs}^{+} / \mathrm{Sr}^{2+}$ concentration on $\mathrm{Cs}^{+} / \mathrm{Sr}^{2+}$ breakthrough

$\mathrm{Cs}^{+}$concentrations showed early breakthrough compared to the 'Harwell Reference' profile (Fig. 2b).

Unlike the $\mathrm{Cs}^{+}$experiments, increasing $\mathrm{Sr}^{2+}$ concentration in the feed (Fig. 2c) has little effect on the breakthrough up to $30,000 \mathrm{BV}$. This was due to the superior performance of this sample of ion exchanger with $\mathrm{Sr}^{2+}$ in comparison to $\mathrm{Cs}^{+}$(Fig. 2b). In addition, $\mathrm{Sr}^{2+}$ concentrations were much lower than $\mathrm{Cs}^{+}$in the experiments (mM vs. $\mu \mathrm{M}$ ). This meant that, in contrast to the $\mathrm{Cs}^{+}$experiments, the exchanger was not approaching saturation towards the end of the experiment at any of the concentrations used.

\section{Effect of $\mathrm{Ca}^{2+}$ and $\mathrm{Mg}^{2+}$ concentration}

Figure $3 \mathrm{a}, \mathrm{b}$ shows the effect of increasing Ca concentration on $\mathrm{Cs}^{+}$and $\mathrm{Sr}^{2+}$ breakthrough at a fixed concentration of $\mathrm{Mg}(0.6 \mathrm{ppm}=0.02 \mathrm{mM})$. When no Ca was present in the feed, there were breakthroughs of $2.5 \% \mathrm{Cs}^{+}$and $0.2 \% \mathrm{Sr}^{2+}$ after $20 \mathrm{kBV}$. These were better than the standard breakthrough curve, which had a Ca concentration of $0.04 \mathrm{mM}$. With $0.02 \mathrm{mM}$ of Ca present, the breakthrough values after $20 \mathrm{kBV}$ have increased to $6 \%$ and $1 \%$ for Cs and Sr, respectively. When the concentration was increased to $0.05 \mathrm{mM}$ in the feed, the breakthrough values for $\mathrm{Cs}$ and $\mathrm{Sr}$ after 20 $\mathrm{kBV}$ were $8.4 \%$ and $3.3 \%$. When the Ca concentration had increased to $0.15 \mathrm{mM}$, the breakthrough at $20 \mathrm{kBV}$ was $12 \%$ and $25 \%$ for $\mathrm{Cs}^{+}$and $\mathrm{Sr}^{2+}$.

Figure $3 \mathrm{c}$ shows the effect of increasing Ca concentration on breakthrough at a fixed $\mathrm{Mg}$ concentration $(2.0 \mathrm{ppm}=0.08 \mathrm{mM})$. The repeat data $\left(0.07 \mathrm{mM} \mathrm{Ca}^{2+}\right)$ showed good agreement. The data (Fig. 3c) showed the expected trend, with earlier breakthroughs as Ca concentration increased. Further, increasing the $\mathrm{Mg}^{2+}$ concentration also had the expected effect, and for systems with identical Ca concentrations, earlier breakthrough was observed at the higher $\mathrm{Mg}^{2+}$ concentration (compare the positions of plots with 0.07 and $0.15 \mathrm{mM} \mathrm{Ca}^{2+}$ in Fig. $3 \mathrm{~b}, \mathrm{c}$ ).

Repeat experiments are shown in Fig. 3 for the $0.07 \mathrm{mM}$ $\mathrm{Ca}$ concentration, which gives an indication of the experimental uncertainties. Although the repeat curves were close for the $\mathrm{Cs}^{+}$data in Fig. 3a and the $\mathrm{Sr}^{2+}$ data in Fig. 3c, there was a greater difference for the $\mathrm{Sr}^{2+}$ experiments shown in Fig. 3b. The reason was unclear and could be due to problems associated with the column experiment or due to the natural variability of clinoptilolite (See below). The order of the profiles in Fig. 3 follows that expected from the zeolite selectivity series, apart from the relative positions of the Harwell reference curves $(0.04 \mathrm{mM} \mathrm{Ca})$ and the $0.02 \mathrm{mM}$ Ca plot in Fig. 3a. Given the magnitudes of the differences
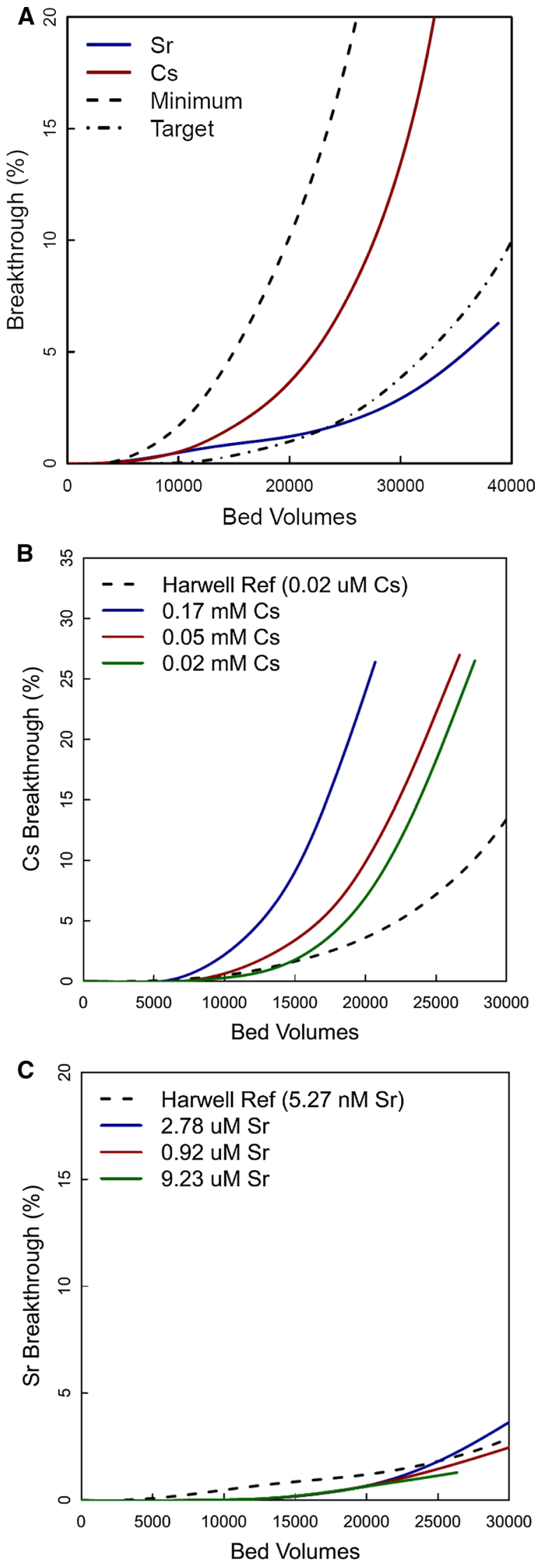
Fig. 3 Top and middle - effect of Ca concentration on $\mathrm{Cs}^{+}$and $\mathrm{Sr}^{2+}$. breakthrough at $[\mathrm{Mg}]=0.02 \mathrm{mM}(0.6 \mathrm{ppm})$; bottom-effect of $\mathrm{Ca}$ concentration on $\mathrm{Sr}^{2+}$ breakthrough at $[\mathrm{Mg}]=2.0 \mathrm{ppm}$

between the repeat experiments in Fig. 3b, this may be a result of experimental uncertainties and natural variations in the zeolite composition.

Figure 4a shows the effect of $\mathrm{Mg}^{2+}$ concentration ( 0.02 and $0.08 \mathrm{mM}$ ), at a fixed $\mathrm{Ca}$ concentration of $0.07 \mathrm{mM}$, on $\mathrm{Cs}^{+}$breakthrough. The effect of $\mathrm{Mg}^{2+}$ concentration on $\mathrm{Cs}^{+}$ breakthrough was as expected, with earlier breakthrough at the higher $\mathrm{Mg}^{2+}$ concentration. Figure $4 \mathrm{~b}$ shows the effect of $\mathrm{Mg}^{2+}$ concentration on $\mathrm{Sr}^{2+}$ breakthrough, this time at Ca concentrations of 0.07 and $0.15 \mathrm{mM}$. Qualitatively, the combined $\mathrm{Ca}^{2+}$ and $\mathrm{Mg}^{2+}$ concentrations had a greater effect on $\mathrm{Sr}^{2+}$ than on $\mathrm{Cs}^{+}$(compare difference between plots in Fig. $4 a, b$ and the Harwell Reference curves). The plots in Fig. $4 \mathrm{a}, \mathrm{b}$ follow the expected trend, with earlier breakthroughs observed as $\mathrm{Mg}$ and $\mathrm{Ca}$ concentrations increase. As would be expected, comparing Figs. 3 and 4, the effects of $\mathrm{Ca}^{2+}$ and $\mathrm{Mg}^{2+}$ were additive.

Given the similarity in the binding sites of $\mathrm{Ca}^{2+}$ and $\mathrm{Sr}^{2+}$ in clinoptilolite (see above; $[17,18]$ ), it is not surprising that $\mathrm{Ca}^{2+}$ is very effective at suppressing $\mathrm{Sr}^{2+}$ uptake. However, $\mathrm{Mg}^{2+}$ seems to be almost as effective as a competing ion. Given the difference in charge density between $\mathrm{Cs}^{+}$and $\mathrm{Ca}^{2+} / \mathrm{Mg}^{2+}$, we would expect the Group II ions to have less effect on $\mathrm{Cs}^{+}$than for $\mathrm{Sr}^{2+}$, and this seems to be the case. However, $\mathrm{Ca}^{2+}$ and $\mathrm{Mg}^{2+}$ can suppress binding to some extent, Smyth et al. [6] has suggested that $\mathrm{Cs}^{+}$exchange is more complex than simple one for one substitution (see above), and this may explain the observations.

\section{Effect of $\mathrm{Na}^{+}$concentration}

Experiments were performed with seven different concentrations of $\mathrm{Na}$. The breakthrough curves for $\mathrm{Cs}$ and $\mathrm{Sr}$ for these tests are shown in Fig. 4c, d. The curves with $4.34 \mathrm{mM}$ $\mathrm{Na}^{+}$were effectively repeats of the Harwell reference curves. For the $\mathrm{Cs}^{+}$data, the curves were in the expected order, with progressively earlier breakthrough as Na concentration increased. The difference between the Harwell reference curve and the $4.34 \mathrm{mM}$ Na curve was probably due to natural variation in the clinoptilolite and experimental uncertainty (see below). As would be expected, due to competition effects, breakthrough occurs earlier with increasing $\mathrm{Na}^{+}$concentration, although higher concentrations in comparison to $\mathrm{Mg}^{2+}$ and $\mathrm{Ca}^{2+}$ were required to have an effect, which would be expected given the similarities between the $\mathrm{Ca}^{2+}$ and $\mathrm{Sr}^{2+}$ binding sites $[17,18]$.

Generally, the same concentrations of Na had a smaller effect on $\mathrm{Sr}^{2+}$ than $\mathrm{Cs}^{+}$. Given the variation in behaviour for the $4.34 \mathrm{mM}$ experiment and the Harwell reference curve,
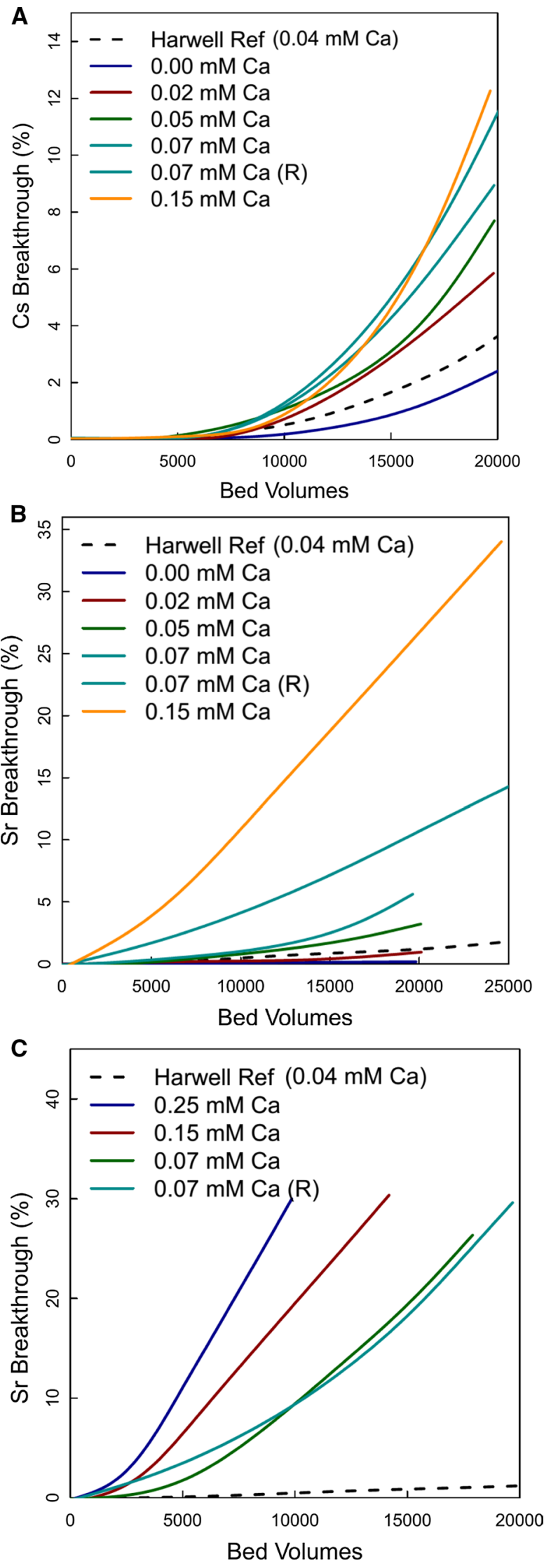

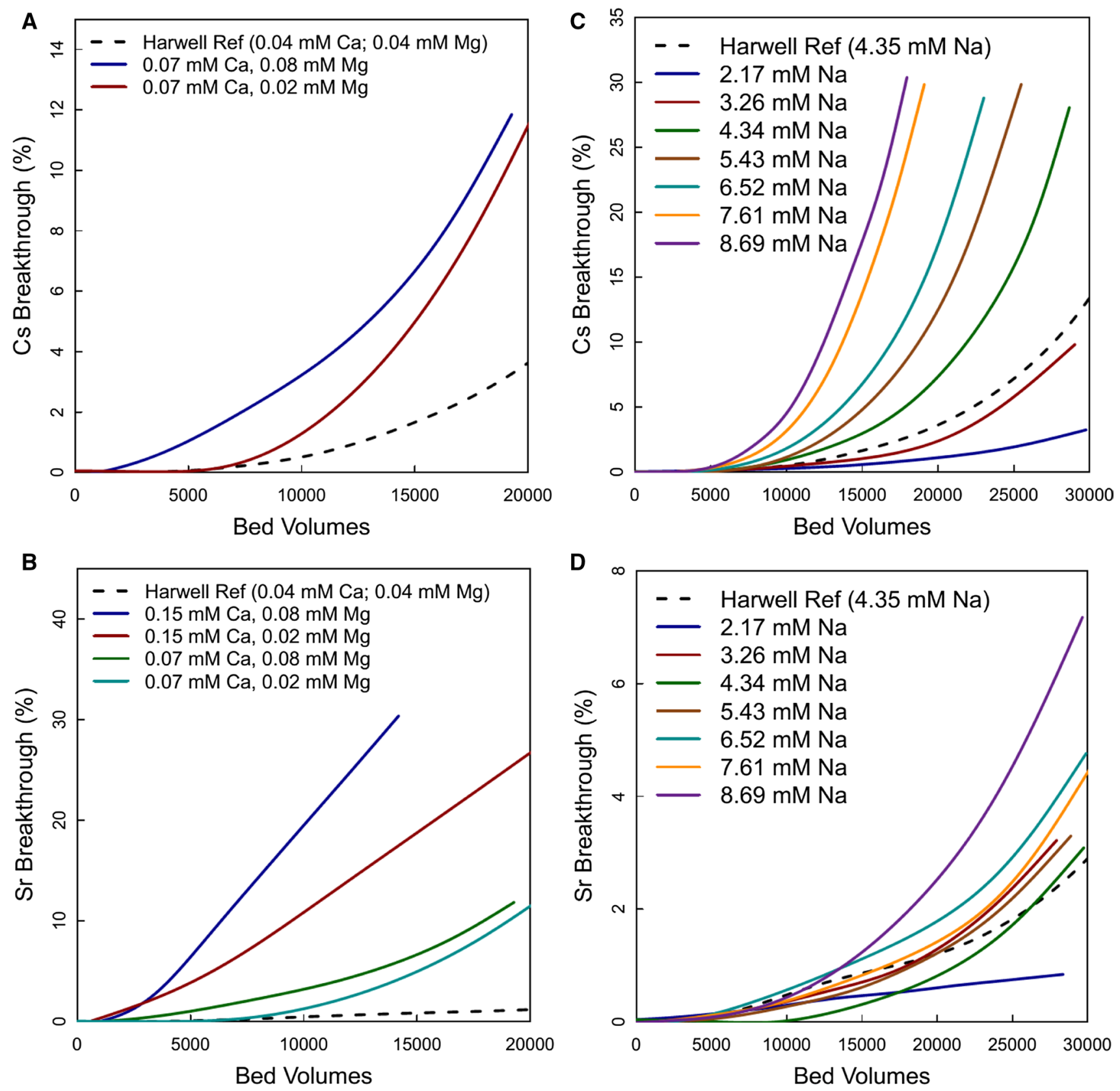

Fig. 4 Effect of $\left[\mathrm{Mg}^{2+}\right]$ on $\mathrm{Cs}^{+} / \mathrm{Sr}^{2+}$ breakthrough at $\left[\mathrm{Ca}^{2+}\right]=0.15$ and $0.074 \mathrm{mM}(3$ and $6 \mathrm{ppm})$-left hand plots; effect of $\left[\mathrm{Na}^{+}\right]$on $\mathrm{Cs}^{+} / \mathrm{Sr}^{2+}$ breakthrough (right hand plots)

for $\mathrm{Cs}^{+}$it seems that the differences in behaviour below $\mathrm{Na}$ concentrations of $8.69 \mathrm{mM} \mathrm{Na}$ were probably not significant.

\section{Clinoptilolite variability}

During the initial characterisation work, samples from several boreholes across the clinoptilolite deposit were analysed in $5 \mathrm{~mL}$ columns to assess their variability. Their location is shown in Fig. 5. Column experiments, all using the standard
Harwell simulant recipe (Table 1), were used to identify that part of the deposit that should be mined for use in SIXEP.

Figure $6 \mathrm{a}, \mathrm{b}$ shows the $\mathrm{Cs}^{+}$and $\mathrm{Sr}^{2+}$ breakthrough data for each of the boreholes. There was significant variability in the behaviour of the clinoptilolite obtained from the various boreholes at Mud Hills. Very few of the samples corresponded to the performance reported for the Harwell Reference Curves (Fig. 2a).

The worst performing zeolite samples failed to meet the minimum performance curves for both $\mathrm{Cs}^{+}$and $\mathrm{Sr}^{2+}$. At the 


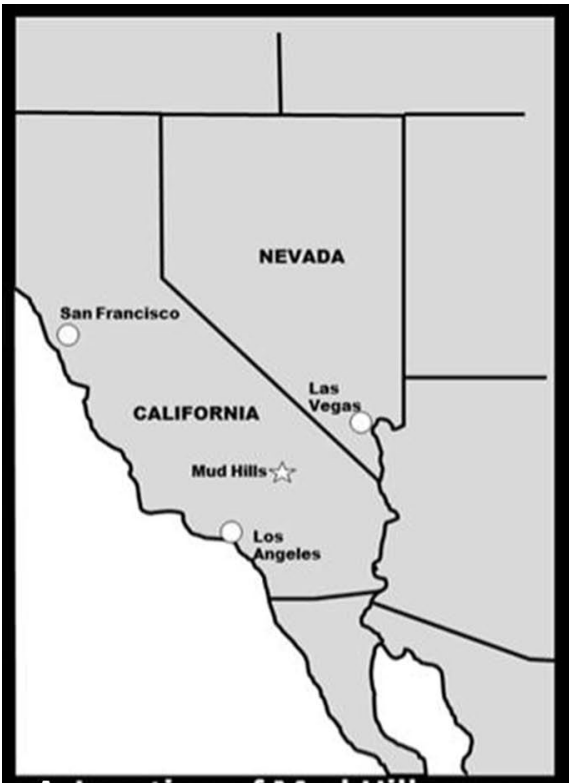

A Location of Mud Hills area

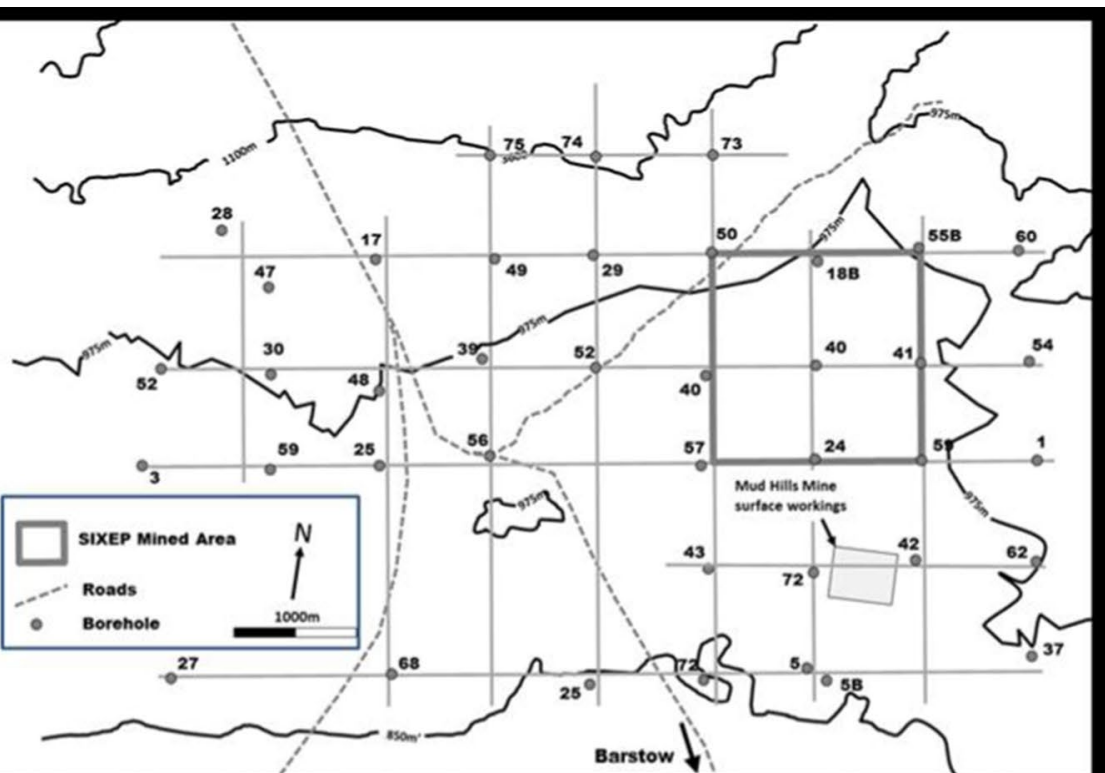

B Location of SIXEP mined area and old mine surface workings

Fig. 5 Map of the Mud hills clinoptilolite showing the location of the sample boreholes

other extreme, the best performing samples were comparable with the Harwell reference curve for $\mathrm{Sr}^{2+}$, and significantly better than the Harwell reference curve for $\mathrm{Cs}^{+}$. In fact, the sample used for the Harwell reference curve represented optimum behaviour for $\mathrm{Sr}^{2+}$ retention for the deposit, and was not representative of most of the material.

Based on the data in Fig. 6a, b, an area of the site was identified as a source of clinoptilolite for SIXEP, which is shown as a green square in Fig. 5 (boreholes 50B, 18B, 55B, $40,41,57,24 \& 58$ ). The mined area was of sufficient size to provide enough material for twice the expected lifetime requirement of SIXEP. Figure $6 \mathrm{c}, \mathrm{d}$ shows the breakthrough profiles for samples from the mined area for $\mathrm{Cs}^{+}$and $\mathrm{Sr}^{2+}$. Even in this smaller area, considerable variability in performance for $\mathrm{Cs}^{+}$and $\mathrm{Sr}^{2+}$ was observed. Despite the variability, nearly all the samples fell between the minimum and target performances. There were two exceptions. The $\mathrm{Sr}^{2+}$ curve for borehole 24 failed to meet the minimum performance values at low BV, but was within target and minimum after $\sim 13 \mathrm{kBV}$ (representing breakthrough of up to $3 \%$ ). For the $\mathrm{Cs}^{+}$curves, borehole 55B exceeds the minimum curve above approximately $26 \mathrm{kBV}$, and by extrapolation, borehole $50 \mathrm{~B}$ would have exceeded the minimum curve at $29 \mathrm{kBV}$ if the experiment had continued. These excursions outside the minimum performance were acceptable, as the number of BV to which the clinoptilolite is exposed in SIXEP rarely exceeds 25,000 .

A composite sample was made from a combination of the material from each borehole in the SIXEP mined area (Fig. 5). This composite sample was then used in column experiments. The resulting breakthrough curves are shown in Fig. $6 \mathrm{c}$, d. The composite samples fell between the minimum and target breakthrough profiles for both $\mathrm{Cs}^{+}$and $\mathrm{Sr}^{2+}$, although neither displayed a performance comparable to the Harwell Reference curves.

Most samples displayed an ion exchange preference for either $\mathrm{Cs}^{+}$or $\mathrm{Sr}^{2+}$, and in doing so were poorer exchangers for the other ion. This was evident in the mined SIXEP area data, e.g., borehole 58 gave one of the best ion exchange profiles for $\mathrm{Cs}^{+}$, but one of the worst profiles for $\mathrm{Sr}^{2+}$. The exceptions to this, where there was no strong preference for either ion, were boreholes 49 and 29, and to a lesser extent 17 and 47. It seems that samples from the North of the SIXEP mined area showed a preference for $\mathrm{Sr}^{2+}$, whilst those from the South preferred $\mathrm{Cs}^{+}$. No chemical analyses were performed at the time of the work, but selectivity would be expected to depend upon the $\mathrm{Si} / \mathrm{Al}$ ratio of the clinoptilolite (see above; [23]).

\section{Phase 2 experiments}

Approximately 25 years after the initial work to characterise the ion exchange performance of the clinoptilolite, a further series of column tests were initiated. These used clinoptilolite from a different location to that used in the earlier tests. Given the variability in the performance of the material across the mined area (Fig. 6c, d), the baseline performance of the material to the standard feed simulant would be expected to be different, but the same general trends would 

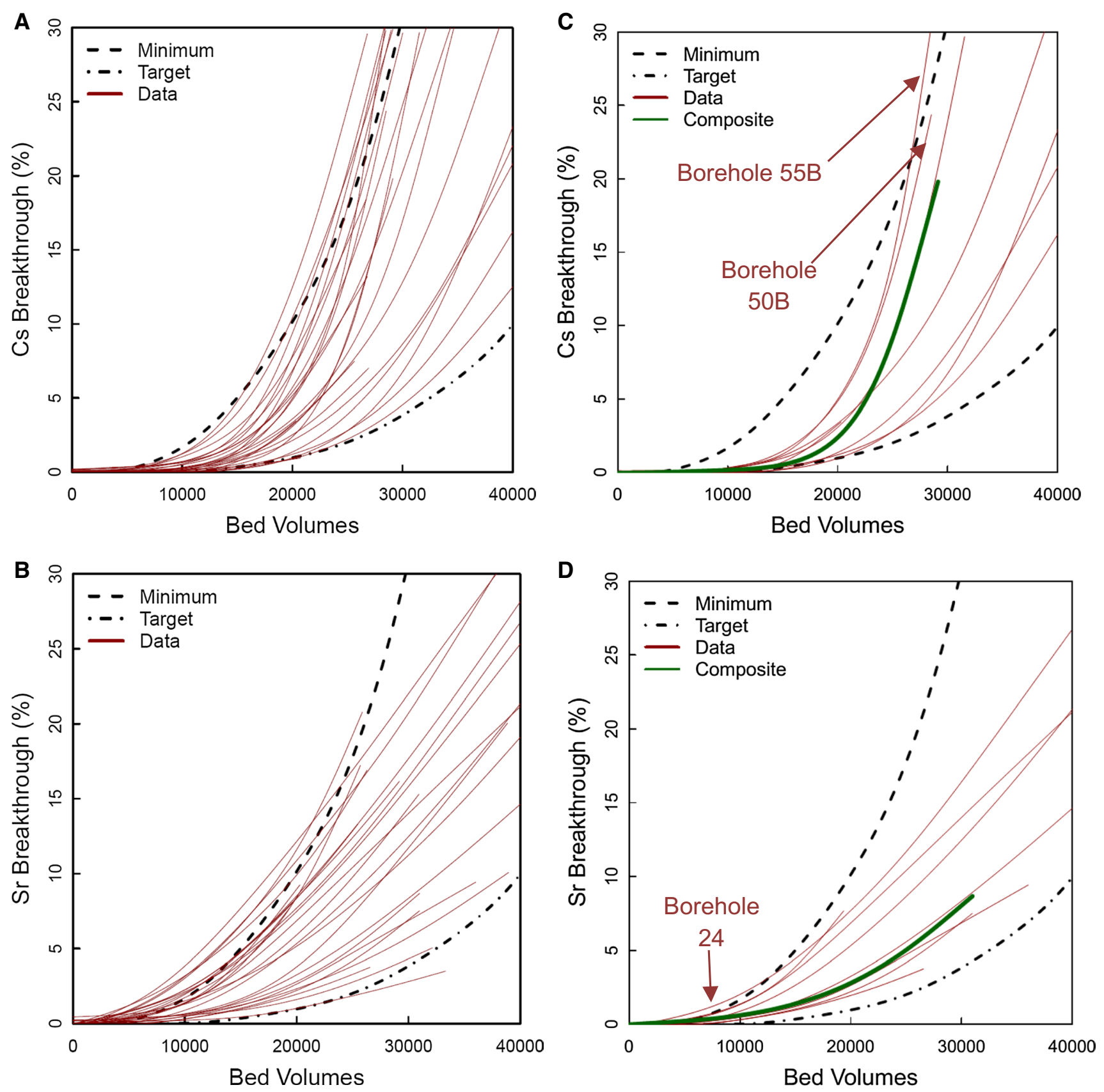

Fig. $6 \mathrm{Sr}^{2+} / \mathrm{Cs}^{+}$column breakthrough profiles collected from each borehole in the Mudhills mine (left hand plots); profiles for samples from the SIXEP mined area (right hand plots)

be expected: e.g., earlier breakthrough with increasing competing ion concentration.

\section{Effect of $\mathrm{K}^{+}$concentration}

Breakthrough profiles generated with known concentrations of $\mathrm{K}^{+}$are given for $\mathrm{Cs}^{+}$and $\mathrm{Sr}^{2+}$ (Fig. 7a, b). Column experiments were also performed with a feed solution containing no added $\mathrm{K}^{+}$. For comparison, the Harwell Reference curves from Fig. 2a are also plotted in the figures.

Increasing the $\mathrm{K}^{+}$concentration led to an expected reduction in capacity for $\mathrm{Cs}^{+}$and $\mathrm{Sr}^{2+}$. As the $\mathrm{K}^{+}$concentration was increased from 0.02 to $0.12 \mathrm{mM}(1-5 \mathrm{ppm})$, the breakthrough profile was shifted further to the left. The number of $\mathrm{BV}$ required for a breakthrough of 5\% illustrated the effect of $\mathrm{K}^{+}$on the behaviour. For $\mathrm{Cs}^{+}, 5 \%$ breakthrough occurred at: $23 ; 21$ and $17.5 \mathrm{kBV}$, for $0,0.02$ and $0.12 \mathrm{mM} \mathrm{K}^{+}$, 

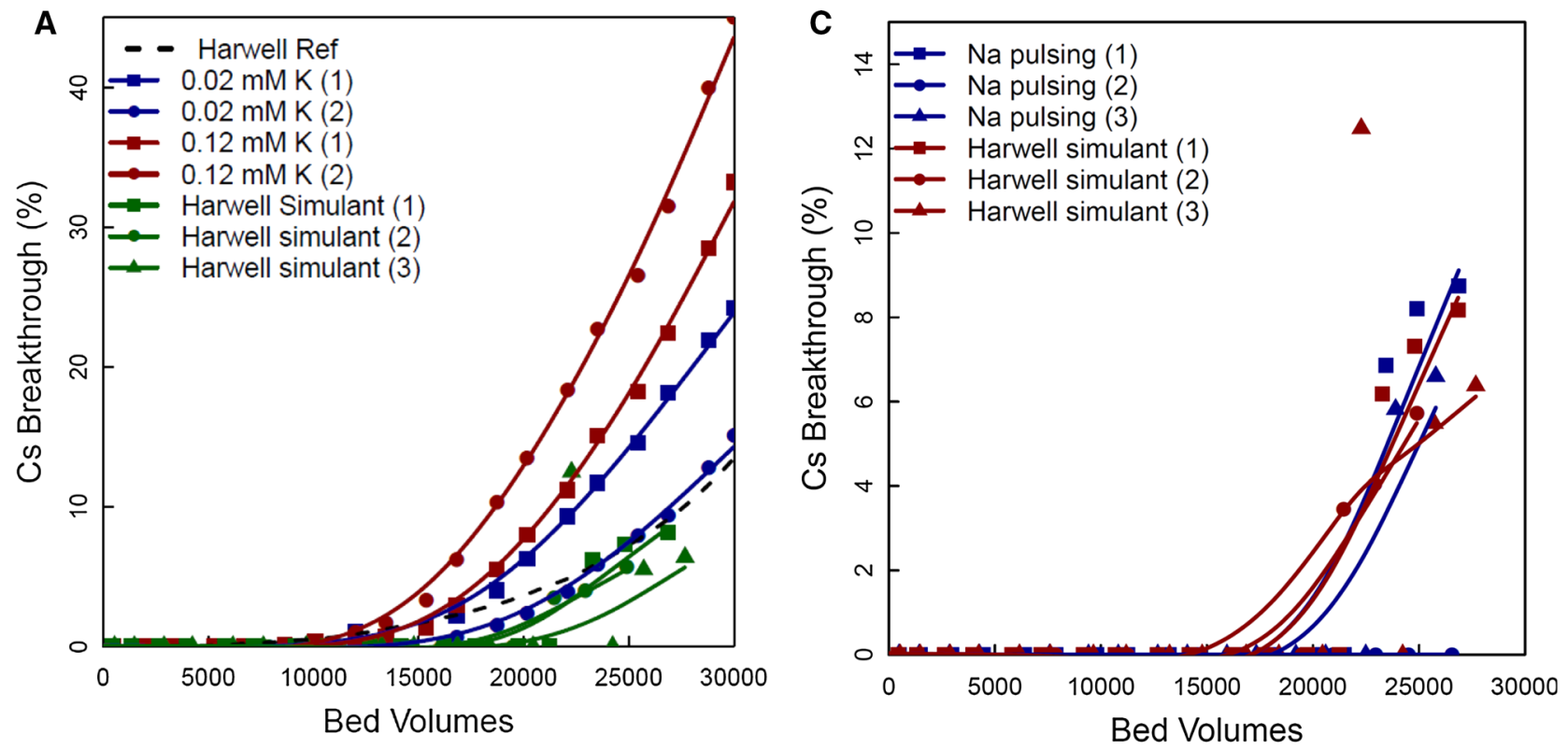

$\mathbf{B}$
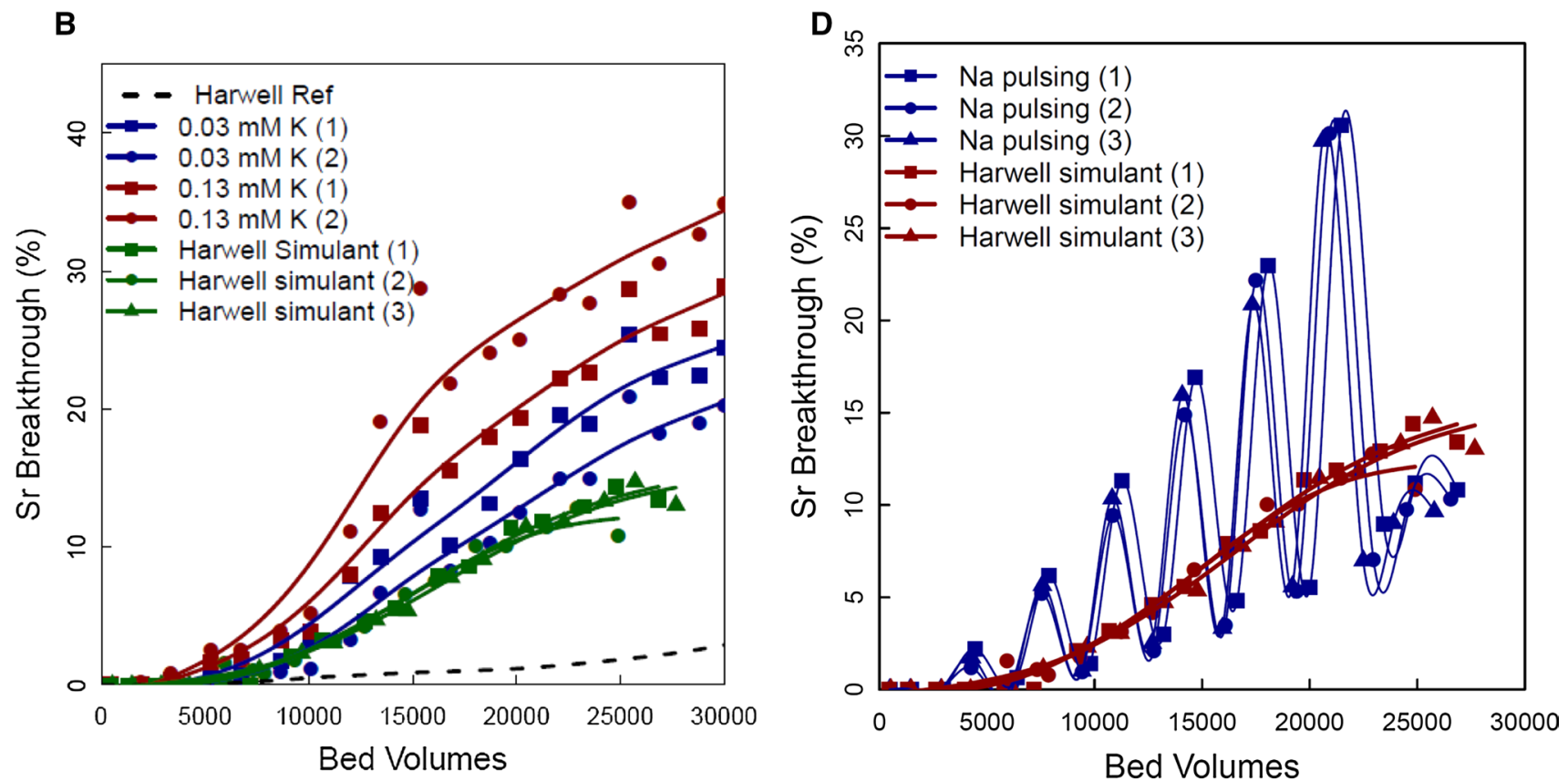

Fig. 7 Effect of $\mathrm{K}^{+}$on breakthrough of $\mathrm{Cs}^{+} / \mathrm{Sr}^{2+}$ - left hand plots; $\mathrm{Cs}^{+} / \mathrm{Sr}^{2+}$ breakthrough in $\mathrm{Na}^{+}$pulsing experiments-right hand plots

respectively. In the case of $\mathrm{Sr}^{2+}, 5 \%$ breakthrough occurred at: $13,11.5$ and $9.5 \mathrm{kBV}$, respectively. Figure $7 \mathrm{a}, \mathrm{b}$ shows the results of replicate measurements for both $\mathrm{K}^{+}$concentrations (duplicates) and for the unaltered Harwell simulant (triplicates). For all systems, there was some variation from one individual column experiment to the next, but it is still possible to discern the effect of the $\mathrm{K}^{+}$on breakthrough. There were significant differences between the Harwell simulant breakthrough curves recorded in the second phase experiment (green lines, Fig. 7a, b) and the original Harwell Reference Curves, particularly for $\mathrm{Sr}^{2+}$. Given the variation in performance across the Mud Hills deposit and even within the smaller mined area (Fig. 6), this was to be expected. Clearly, in these systems, it is important to compare results for the same sample of zeolite.

\section{Effect of Na pulsing}

With the commencement of legacy waste retrieval operations and decommissioning activities at Sellafield, changes in the composition of the feeds that will be treated by SIXEP are expected. It has been suggested that significant 
improvements in controlling the levels of competing ions entering SIXEP could be achieved by increasing the $\mathrm{pH}$ of the feed liquor, since that would result in the removal of soluble $\mathrm{Mg}$, and potentially $\mathrm{Sr}$, from the solution, as insoluble hydroxides. This would be expected to have a positive impact on performance. However, it would also result in increased Na concentrations in the SIXEP feed solutions.

Column trials were conducted to investigate the effect of pulsing the $\mathrm{Na}$ concentration, from a $100 \mathrm{ppm}$ base-level (Harwell Reference simulant) to a $250 \mathrm{ppm}(4.3-10.8 \mathrm{mM})$ 'worse-case' scenario, based on the maximum expected $\mathrm{pH}$ (12). The simulant with high Na concentration was based on the standard Harwell simulant, with an additional dose of $\mathrm{Na}$ ions, which was added as $\mathrm{Na}$ bicarbonate, since any additional $\mathrm{NaOH}$ added to the solutions would be converted to $\mathrm{NaHCO}_{3}$ in the carbonation tower, prior to the clinoptilolite columns. The high Na simulant was injected for approximately 3 days before returning to the original Harwell simulant for the remainder of each week. This regime was selected because of the ease of running the experimental trials and does not replicate a specific process at Sellafield. No Na pulsing was attempted during the first week of the trial to allow the system to stabilise and pulsing was terminated 2 weeks before the end of the experiment to assess how the system would respond to a return to the standard Harwell simulant.

The ${ }^{137} \mathrm{Cs}$ breakthrough profiles for the Na pulsed columns are shown in Fig. 7c. Breakthrough profiles of the columns run with the standard Harwell simulant have also been included for comparison. There was good agreement between the triplicate experiments. The shape of the breakthrough profile was similar for each trial, although the onset of breakthrough varies slightly. There was little difference between the $\mathrm{Cs}^{+}$breakthrough profiles observed for the $\mathrm{Na}$ pulsed columns and the Harwell simulant only columns. No significant breakthrough of ${ }^{137} \mathrm{Cs}$ was observed in any of the trials until approximately $20 \mathrm{kBV}$ of solution had been processed. The affinity of clinoptilolite is much greater for Cs than for $\mathrm{Na}$, although it was expected that the increase in the $\mathrm{Na}$ ions might result in a greater competing common ion effect for Cs exchange. This was not observed in these trials. $\mathrm{The}^{2+} \mathrm{r}^{2+}$ breakthrough profiles for the Na pulsed columns are shown in Fig. 7d.

Increased discharges of $\mathrm{Sr}^{2+}$ from the column were observed during periods when the high Na simulant was being fed through the columns. The effect was reproducible, as the three replicate columns exhibited similar discharge profiles (Fig. 7d). The effect appears to be relatively short-lived, as the $\mathrm{Sr}^{2+}$ breakthrough in the pulsed columns returned to a level slightly below that observed for the Harwell simulant (low $\left[\mathrm{Na}^{+}\right]$) by the next sampling point after the simulant feed had been switched back to the low Na (Harwell) feed. This shows that the $\mathrm{Na}$ exchange reaction kinetics are relatively fast, and is consistent with the observations of Faghihian et al. [29]. However, total $\mathrm{Sr}^{2+}$ output from the $\mathrm{Na}^{+}$pulsed columns was greater than for the non-pulsed columns by approximately $40 \%$ (based on the area under the curve).

The apparent improved performance, compared to that of the lower $\mathrm{Na}$ columns, when the flow of the high $\mathrm{Na}$ simulant was stopped could be attributed to a pre-conditioning effect on the clinoptilolite columns. The Na ions will effectively replace the other ions in the clinoptilolite. This increases the number of $\mathrm{Na}$ sites present on the clinoptilolite (i.e. an increased effective CEC), which will increase the likelihood of $\mathrm{Sr}^{2+}$ uptake once the $\mathrm{Na}$ concentration is reduced, and hence improve the removal of Sr. Beyond the fact that clinoptilolite shows a low selectivity for $\mathrm{Na}^{+}[4,5$, 32], it has been suggested that exchange for $\mathrm{Na}$ is quicker [27], and so in a system with a short residence time like this, a Na exchanged material should be more effective.

As the experiment progressed, the oscillations became more pronounced, as the total $\mathrm{Sr}^{2+}$ loading of the column increased, and so more $\mathrm{Sr}^{2+}$ was displaced when the Na concentration increased.

In the experiments reported here, the columns were pristine, i.e., "as mined" before a high $\mathrm{Na}$ feed was introduced. Given that the SIXEP plant operates two columns in series, it is expected that there will always be some activity associated with the lead bed. Therefore, some of the ions being removed by a high $\mathrm{Na}$ feed would be radio-isotopes. The extent of this effect would probably depend upon the loading state of the clinoptilolite prior to the increase in $\mathrm{Na}$ concentration.

It is important to contrast the response of the clinoptilolite sample used in the later pulsed $\mathrm{Na}$ experiments (Fig. 7c, d) with that of the original, Harwell sample (Fig. 4c, d). The uptake of $\mathrm{Sr}^{2+}$ by the clinoptilolite used in the second phase experiments (Fig. 7d) was more sensitive to competing $\mathrm{Na}$ ions than that observed during the first phase (Fig. 4d). As discussed above, the original sample performance represents the optimum for $\mathrm{Sr}^{2+}$, and for this sample, $\mathrm{Na}^{+}$was not able to compete. The $\mathrm{Sr}^{2+}$ affinity of the sample used later is lower, and so $\mathrm{Na}^{+}$can compete. Although divalent competitors are expected to be the strongest competitors based on structural arguments [17, 18], Um and Papelis [17] have suggested that direct competition with $\mathrm{Na}^{+}$for exchange sites may be possible. The performance for $\mathrm{Cs}^{+}$shows the opposite effect, with the original sample (Fig. 4c) more sensitive than the second phase sample (Fig. 7c).

\section{Modelling}

There are a limited number of models of radionuclide interactions with clinoptilolite described in the literature. Valcke et al. [12,13] developed a three-site model for 
predicting the binding of trace $\mathrm{Sr}^{2+}$ and $\mathrm{Cs}^{+}$by clinoptilolite at equilibrium that could explain competition by $\mathrm{Ca}^{2+}$, $\mathrm{Mg}^{2+}$ and $\mathrm{K}^{+}$. Pabalan and Bertetti [33] successfully used a model, which was based on a Margules solid solution approach for the zeolite components and Pitzer equations for the activities of the ions in solution, to describe the equilibrium uptake of $\mathrm{Sr}^{2+}$.

Nikashina et al. [10] developed a model of $\mathrm{Sr}^{2+}$ interaction with clinoptilolite, which assumed that there were two distinct regions where radionuclide exchange could take place, the mesopores and the micropores. Initial transfer of metal ions to the mesopores was described with a kinetic equation. This was followed by slower diffusion into the micropores. The model was able to describe the results of column experiments including those where the flow was interrupted. Recently, Yin et al. [34] have used a kinetic sorption model, rather than ion exchange, to simulate the removal of ${ }^{90} \mathrm{Sr}$ from contaminated water by clinoptilolite. The authors found that the apparent sorption rate constant was a function of the pore water velocity, rate constant decreasing as flow rate increased.

A coupled chemical transport model was developed to describe the behaviour of $\mathrm{Cs}^{+}$and $\mathrm{Sr}^{2+}$ in SIXEP. The model was calibrated using the data from the original Harwell experiments only. Given the short residence times in the SIXEP column compared to the time required for equilibrium, a thermodynamic approach, such as those of Valcke et al. [12,13] and Pabalan and Bertetti [33], were not appropriate. Instead, a kinetic ion exchange approach was adopted. The model assumes that the ionic concentration at a given column depth is independent of radial position. The model assumes that the columns are 'well designed', i.e., edge effects are not significant. Species are assumed to exist in one of two phases. They are either in the solution (mobile) or on the clinoptilolite (static). Ion exchange reactions represent the exchange between the mobile and static phases. To calculate the behaviour of the ions, the model splits the column into several discrete sections or nodes. Similarly, the total simulation time (in this case, the column run time) is split into several discrete time steps. At each node, and for each time step, a calculation is made of the ion exchange chemistry and the associated changes in solution concentration are calculated due to fluid flow and dispersion.

The flow of liquid through the column is pressure-driven incompressible fluid flow and is assumed to be determined entirely by the feed volumetric flow rate. There is an excluded volume due to the particles of clinoptilolite. This results in a higher face velocity for the fluid, scaled by the ratio of the total volume to the excluded volume. In addition to the concentration change at a given depth down the column due to fluid flow, there is also an axial dispersion of the concentration due to diffusion. This is modelled using the second derivative version of Fick's Law [35]. The resulting change in concentration with time, due to fluid flow down the column and diffusion/dispersion is given by (2),

$$
\frac{d C_{i}}{\mathrm{~d} t}=V_{\mathrm{liq}} \frac{d C_{i}}{\mathrm{~d} z}-D_{i} \frac{d^{2} C_{i}}{\mathrm{~d} z^{2}}
$$

$\frac{d C_{\mathrm{liq}, i, z}}{\mathrm{~d} t}=V_{\mathrm{liq}} \frac{d C_{\mathrm{liq}, i, z}}{\mathrm{~d} z}-D_{i} \frac{d^{2} C_{\mathrm{liq}, i, z}}{\mathrm{~d} z^{2}}$

where $C_{\text {liqi } i z}$ is the concentration of component $i$ in the liquid phase at depth $z, D_{i}$ is the dispersion coefficient of component $i$, and $V_{\text {liq }}$ is the face velocity of the liquid and is given by:

$V_{\text {liq }}=\left(\frac{\text { Feed Volumetric Flowrate }}{\text { Column Area } \times \text { Ratio of Total to Excluded Volume }}\right)$

The model was implemented within the gPROMS process modelling code, which is computationally efficient and robust, particularly with respect to solving partial differential equations.

The basis for the simulation of the ion exchange equilibrium is the law of mass action [5] (Dyer 2007). In this case, there is a model requirement for the clinoptilolite to be charge balanced at all times. It is assumed that there is no delay due to mass transfer within the exchanger phase, i.e. the surface exchange reaction is the rate limiting step. The model reactions are like the first reaction step in the model of Nikashina et al. [10]. The rate constants describing the ion exchange reactions are specific to each cation pair, as they depend on the specific interaction of each ion with the clinoptilolite, which will be a function of cation size and charge.

As an example, the exchange reaction that takes place between $\mathrm{Na}$ and $\mathrm{Cs}$ is (5):

$\mathrm{Na}_{\mathrm{ex}}^{+}+\mathrm{Cs}_{\mathrm{aq}}^{+} \leftrightarrow \mathrm{Na}_{\mathrm{aq}}^{+}+\mathrm{Cs}_{\mathrm{ex}}^{+}$

where the subscript 'ex' indicates an ion bound to the clinoptilolite, and 'aq' an ion free in solution. A rate equation is defined for this reaction (6):

$\frac{-\mathrm{d}\left[\mathrm{Na}_{\mathrm{ex}}^{+}\right]}{\mathrm{d} t}=k_{\mathrm{NaCs}}\left[\mathrm{Na}_{\mathrm{ex}}^{+}\right]\left[\mathrm{Cs}_{\mathrm{aq}}^{+}\right]-k_{\mathrm{CsNa}}\left[\mathrm{Na}_{\mathrm{aq}}^{+}\right]\left[\mathrm{Cs}_{\mathrm{ex}}^{+}\right]$

where $t$ is the time, square brackets represent concentrations, and $k_{\mathrm{NaCs}}$ and $k_{\mathrm{CsNa}}$ are the forward and backward rate constants, respectively. The same approach was used describe Sr exchange for $\mathrm{Na}$ (7):

$2 \mathrm{Na}_{\mathrm{ex}}^{+}+\mathrm{Sr}_{\mathrm{aq}}^{2+} \leftrightarrow 2 \mathrm{Na}_{\mathrm{aq}}^{+}+\mathrm{Sr}_{\mathrm{ex}}^{2+}$

and:

$\frac{-\mathrm{d}\left[\mathrm{Na}_{\mathrm{ex}}^{+}\right]}{\mathrm{d} t}=k_{\mathrm{NaSr}}\left[\mathrm{Na}_{\mathrm{ex}}^{+}\right]^{2}\left[\mathrm{Sr}_{\mathrm{aq}}^{2+}\right]-k_{\mathrm{CsNa}}\left[\mathrm{Na}_{\mathrm{aq}}^{+}\right]^{2}\left[\mathrm{Sr}_{\mathrm{ex}}^{2+}\right]$ 
where $t$ is the time, square brackets represent concentrations, and $k_{\mathrm{NaSr}}$ and $k_{\mathrm{SrNa}}$ are the forward and backward rate constants, respectively.Thus, to calculate the concentration of ions in the liquid phase with column depth, taking account of ion exchange, an additional interaction term is included in (2) which is the negative of the above rate equations, giving (9):

$\frac{\mathrm{d} C_{\mathrm{liq}, i, z}}{\mathrm{~d} t}=V_{\mathrm{liq}} \frac{\mathrm{d} C_{\mathrm{liq}, i, z}}{\mathrm{~d} z}-D_{i} \frac{\mathrm{d}^{2} C_{\mathrm{liq}, i, z}}{\mathrm{~d} z^{2}}-\frac{\mathrm{d} C_{\mathrm{ex}, i, z}}{\mathrm{~d} z}$

where $C_{\mathrm{ex}, i, z}$ is the concentration of component $i$ on the ion exchanger at depth $z$.

Analogous equations were defined for all monovalent and divalent exchange reactions.

Using such simple ion exchange processes could give a reasonable fit to the $\mathrm{Cs}^{+}$behaviour, but that to the $\mathrm{Sr}^{2+}$ was unrealistic. Given that $\mathrm{Na}^{+}$is the dominant ion exchanged with the clinoptilolite and is in excess in solution, the number of ion exchange equations, and thus rate constants, to be fitted was reduced by the assumption that all ion exchange reactions are mediated by $\mathrm{Na}^{+}$. Rate constants were fitted using the parameter estimation facility within the gPROMS process modelling code.

Figure 8 shows the fit obtained to the $\mathrm{Sr}^{2+}$ Harwell Reference data considering that $\mathrm{Sr}$ only interacts with the surface as $\mathrm{Sr}^{2+}$. It is clear from the figure that the shape of the breakthrough curve is completely different to that of the Harwell reference curve.

Ion selectivity in zeolites is governed by the anionic field (i.e. the concentration and spread of the aluminate units in the structure) and its pore dimensions. Clinoptilolite has a $\mathrm{Si} / \mathrm{Al}$ ratio of 5 (a high silica concentration for this zeolite type), which gives it a low anionic field. This means that

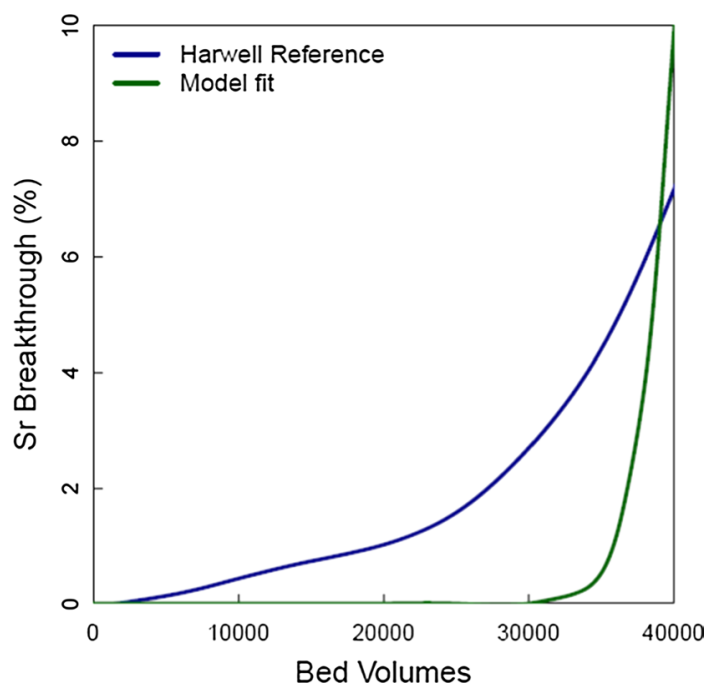

Fig. 8 Original fit to $\mathrm{Sr}^{2+}$ data, excluding bicarbonate species clinoptilolite is expected to be highly selective for cations with a low charge density (see above), and so the better performance of the clinoptilolite for $\mathrm{Sr}^{2+}$ over $\mathrm{Cs}^{+}$shown in Fig. 2 is somewhat surprising.

The solution entering the SIXEP clinoptilolite columns (and the Harwell simulant) has a high background concentration of carbonate/bicarbonate, due to the neutralisation of the alkali in the solution in the carbonation tower. Bicarbonate will react with the divalent Group II cations in the following way (9):

$X_{\mathrm{aq}}^{2+}+\mathrm{HCO}_{3(\mathrm{aq})}^{-} \leftrightarrow X \mathrm{HCO}_{3(\mathrm{aq})}^{+}$

where $X$ is a Group II cation. The PHREEQC equilibrium thermodynamic speciation modelling code [36] was used to calculate the speciation in the Harwell simulant (and SIXEP) column feeds. Figure 9 shows the predicted $\mathrm{Sr}^{2+}$ speciation following the carbonation tower in SIXEP and in the Harwell simulant solution. The $\mathrm{SrHCO}_{3}{ }^{+}$species is present in quantities that are significant, although the free $\mathrm{Sr}^{2+}$ ion is still the dominant form in solution. The hydrolysis species, $[\mathrm{Sr}(\mathrm{OH})]^{+}$, only accounted for a very small fraction of total $\mathrm{Sr}^{2+}(<0.1 \%)$.

The effective size and charge density of a $\left[\mathrm{SrHCO}_{3}\right]^{+}$cationic complex could be a better match for clinoptilolite, and this could be the reason for the improved $\mathrm{Sr}^{2+}$ performance of the material in the presence of $\mathrm{CO}_{3}{ }^{2-} / \mathrm{HCO}_{3}{ }^{-}[25,26]$. The rate of the ion exchange reaction for the complex may be favourable compared to that of the divalent species.

To test whether $\mathrm{HCO}_{3}{ }^{-}$was influencing the interaction of $\mathrm{Sr}^{2+}$ with the clinoptilolite in SIXEP, batch experiments were performed to determine the distribution coefficients $\left(\mathrm{K}_{\mathrm{d}}\right)$ of $\mathrm{Sr}^{2+}$ for a $\mathrm{K}^{+}$exchanged clinoptilolite in $\mathrm{KNO}_{3}$

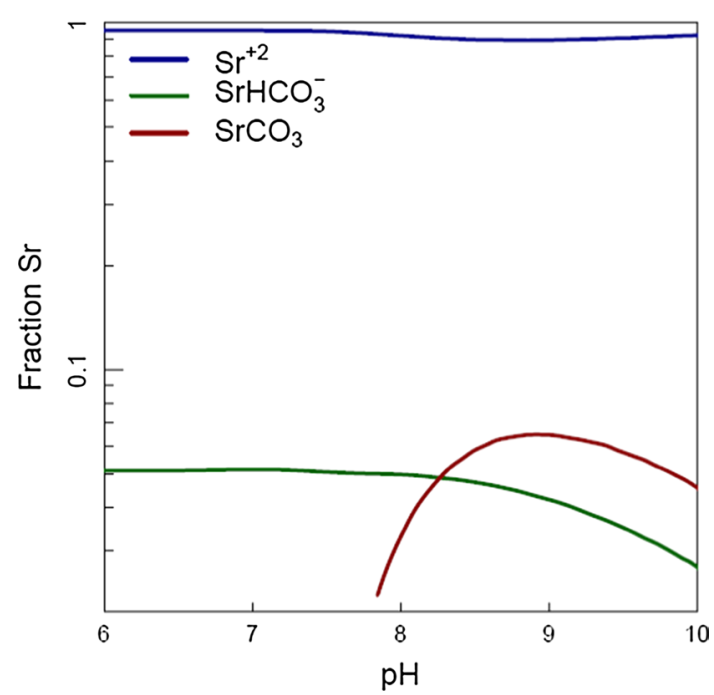

Fig. 9 PHREEQC calculated speciation of $\mathrm{Sr}^{2+}$ in the clinoptilolite columns 
solutions in the concentration range of $0.01-1 \mathrm{M}$ and in the presence and absence of $\mathrm{HCO}_{3}^{-}(1 \mathrm{mM})$. The results are shown in Table 2. An increase was observed in the presence of $\mathrm{HCO}_{3}^{-}$.

Therefore, the model was revised to allow exchange of $\mathrm{HCO}_{3}{ }^{-}$complexes. It was found that the best fits to the $\mathrm{Sr}$ data were obtained using a combination of rate equations for exchange of $\mathrm{Sr}^{2+}$ and $\mathrm{SrHCO}_{3}{ }^{+}$, assuming a distribution of $\left[\mathrm{Sr}^{2+}\right] /\left[\mathrm{SrHCO}_{3}{ }^{+}\right]$ratio of $18.6: 1$, obtained using PHREEQC speciation calculations (Fig. 9).

Given the short residence time in the column, it seems likely that the majority of ion exchange happens at the surface of the clinoptilolite particles during column operation, and thus the diffusivity cannot be used to deduce the mechanism in this case. It is unclear whether a $\mathrm{SrHCO}_{3}{ }^{+}$complex would exist within the clinoptilolite framework. The structural studies of O'Day [18] and Um and Papelis [17] were not performed in systems of high carbonate, and so the lack of bicarbonate incorporation there does not preclude that this takes place in SIXEP. Those studies do show that some coordinated water is retained when $\mathrm{Sr}^{2+}$ is incorporated, and so the ion does have vacant coordination sites. If $\mathrm{SrHCO}_{3}{ }^{+}$is initially sorbed, once it enters the framework it may dissociate to give $\mathrm{Sr}^{2+}$ and $\mathrm{HCO}_{3}{ }^{-}$. As surface ion exchange dominates in the column, the same kinetics would be observed, whether or not the bicarbonate complex dissociates. However, if the complex does dissociate in the framework, then in the long-term, exchange deeper within the particles and the diffusion and the kinetics of Sr behaviour would be dominated by the properties of the divalent cation.

It should be noted that there are several mechanisms that could lead to the observed $\mathrm{Sr}^{2+}$ kinetics, for example, a mass transfer process that is not limited by film diffusion, such as surface sorption from a concentrated solution. The uptake of the bicarbonate complex can explain the column data and is consistent with other observations. However, the observed kinetics may be due to a combination of different processes that are currently unknown. Direct evidence for the bicarbonate mechanism is not available in the literature. Fondeur et al. [37] did find that increasing carbonate concentration increased the $\mathrm{Cs}^{+} \mathrm{K}_{\mathrm{d}}$ for the ion exchanger, IONSIV. However, the authors attributed that

Table 2 Distribution coefficients $\left(K_{d}\right)$ for $\mathrm{Sr}^{2+}$ with $K$ exchanged clinoptilolite in $\mathrm{KNO}_{3}$ solutions, with and without bicarbonate (1 mM)

\begin{tabular}{lll}
\hline$\left[\mathrm{KNO}_{3}\right](\mathrm{M})$ & $\begin{array}{l}\mathrm{Sr}^{2+} K_{d}\left(\mathrm{~mL} \mathrm{~g}^{-1}\right) \mathrm{No} \\
\text { bicarbonate }\end{array}$ & $\begin{array}{l}\mathrm{Sr}^{2+} K_{d}\left(\mathrm{~mL} \mathrm{~g}^{-1}\right) \\
\text { With bicarbonate } \\
(1 \mathrm{mM})\end{array}$ \\
\hline 0.01 & 540 & 980 \\
0.1 & 10 & 35 \\
1 & 0.1 & 17 \\
\hline
\end{tabular}
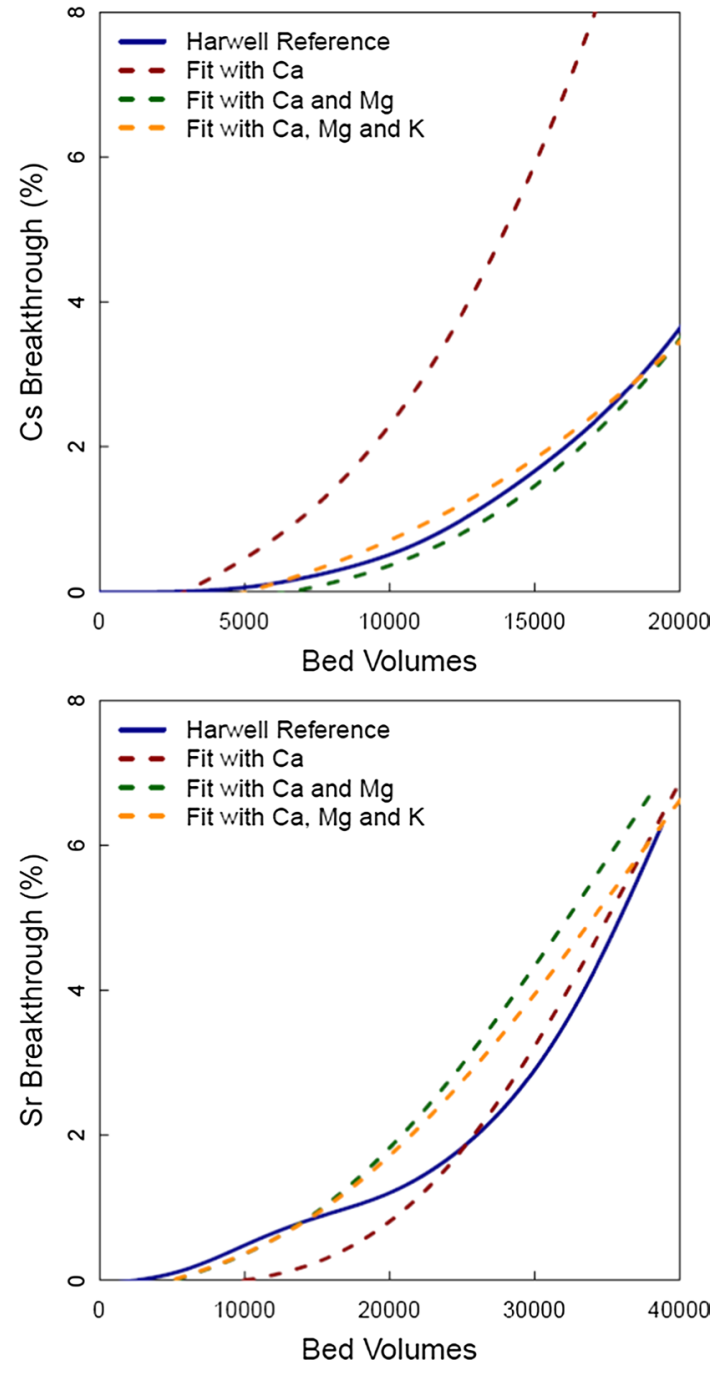

Fig. 10 Model fit to Harwell reference $\mathrm{Cs}^{+} / \mathrm{Sr}^{2+}$ data

to a decrease in the activity of $\mathrm{Na}^{+}$associated with carbonate addition, which reduced competition with $\mathrm{Cs}^{+}$for exchange sites. Elizondo et al. [38] observed an increase in $\mathrm{Sr}^{2+} \mathrm{K}_{\mathrm{d}}$ for clinoptilolite from 1200 to $3700 \mathrm{~mL} / \mathrm{g}$ as $\mathrm{pH}$ increased from 7 to 8 . Their experiments do not appear to

Table 3 Forward and backward rate constants (/s) for the ion exchange of $\mathrm{Na}$ in clinoptilolite with various ions in solution

\begin{tabular}{lll}
\hline & Backward & Forward \\
\hline $\mathrm{Cs}^{+}$ & $4.38 \times 10^{-9}$ & $1.15 \times 10^{-5}$ \\
$\mathrm{Sr}^{2+}$ & $9.17 \times 10^{-17}$ & $1.86 \times 10^{-14}$ \\
$\mathrm{SrHCO}_{3}^{+}$ & $1.46 \times 10^{-8}$ & $9.17 \times 10^{-7}$ \\
$\mathrm{Ca}^{2+}$ & $5.87 \times 10^{-17}$ & $1.50 \times 10^{-16}$ \\
$\mathrm{Mg}^{2+}$ & $1.43 \times 10^{-16}$ & $6.27 \times 10^{-17}$ \\
$\mathrm{MgHCO}_{3}^{+}$ & $2.29 \times 10^{-8}$ & $5.42 \times 10^{-7}$ \\
$\mathrm{~K}^{+}$ & $6.25 \times 10^{-10}$ & $1.38 \times 10^{-6}$ \\
\hline
\end{tabular}


Fig. 11 Ion exchange model fits $\left(\left[\mathrm{Mg}^{2+}\right]=0.02 \mathrm{mM}\right.$ • $(0.6 \mathrm{ppm}) / 0.03 \mathrm{mM}(0.7 \mathrm{ppm})): \mathbf{a} \mathrm{Cs}^{+}$data with $\left[\mathrm{Ca}^{2+}\right]=0.15 \mathrm{mM}$ $(6 \mathrm{ppm}) ; \mathbf{b ~ S r}^{2+}$ data with $\left[\mathrm{Ca}^{2+}\right]=0.07 \mathrm{mM}(3 \mathrm{ppm}) ; \mathbf{c ~ S r}^{2+}$ data with $0.15 \mathrm{mM}(6 \mathrm{ppm})$

have used an inert atmosphere, and so dissolved carbonate concentration would be expected to increase with $\mathrm{pH}$, although the increase could be associated with the change in pH. Smiciklas et al. [39] also observed that the uptake of $\mathrm{Sr}^{2+}$ and $\mathrm{Cs}^{+}$by clinoptilolite increased with $\mathrm{pH}$.

The model incorporating bicarbonate complexes was applied to the original Harwell column data. Figure 10 shows the model fits to the Harwell Reference curves, and Table 3 shows the best fit values of the rate constants. The level of uncertainty on the rate constants could not be calculated directly due to a lack of repeat experiments in the data source used. The value for dispersion was set to $900 \mathrm{dm}^{2} /$ day. The figure shows the results of calculations including competition from: $\mathrm{Ca}^{2+}$ only; $\mathrm{Ca}^{2+}$ and $\mathrm{Mg}^{2+}$; $\mathrm{Ca}^{2+}, \mathrm{Mg}^{2+}$ and $\mathrm{K}^{+}$. Considering the $\mathrm{Cs}^{+}$data, it was clear that competition from both divalent cations was important, because significant improvements were achieved by successively including their effects. This was not surprising given the effect that these ions were found to have in the column tests (Figs. 3 and 4). The addition of $\mathrm{K}^{+}$to the model made less of a difference. For $\mathrm{Sr}^{2+}$, the fit to the data was less good than for $\mathrm{Cs}^{+}$, but represented a clear improvement on the calculation excluding bicarbonate complexes (Fig. 8).

An estimate of parameter uncertainty has been calculated by re-running parameter estimation routines with different combinations of experiments and examining the variability of the predicted parameter values.

Figure 11a shows the fit of the model to some of the other $\mathrm{Cs}^{+}$Harwell data $([\mathrm{Ca}]=6 \mathrm{ppm}=0.15 \mathrm{mM})$. The fit was reasonable, given the inherent variability in the column data. Figure 11b, c shows the fit to the $\mathrm{Sr}^{2+}$ Harwell data ([Ca] $=3$ and $6 \mathrm{ppm}=0.08-0.15 \mathrm{mM}$ ). Although the height of the breakthrough profiles could be reproduced with the modified rate constants, the shape of the experimental curves (straight line vs. curved profile in the modelled results) could not. At this stage, it cannot be attributed to any specific factors. The difference in shape between experiment and model prediction could be due to several possible mechanisms: (1) there are additional chemical reactions other than ion exchange at play (e.g. (co-)precipitation, surface sorption or ion exchange chromatography of colloidal material); (2) a difference in flow patterns between the different experiments (dispersion, flow rate, channelling or other edge effects); (3) variability in the clinoptilolite material. Figure 12 shows the fit to the $\mathrm{Cs}^{+}$Harwell data for a $\mathrm{Mg}^{2+}$ concentration of $2 \mathrm{ppm}(0.08 \mathrm{mM})$. As for the effect of enhanced $\mathrm{Ca}^{2+}$, the fit was reasonably good.
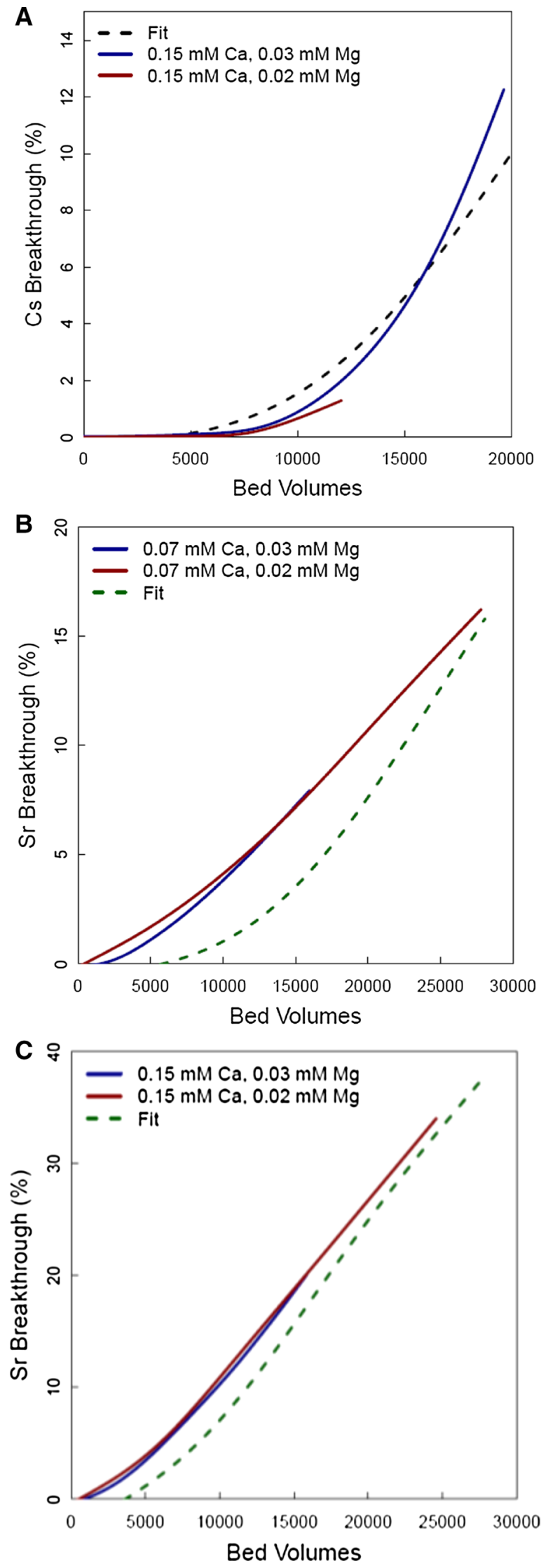


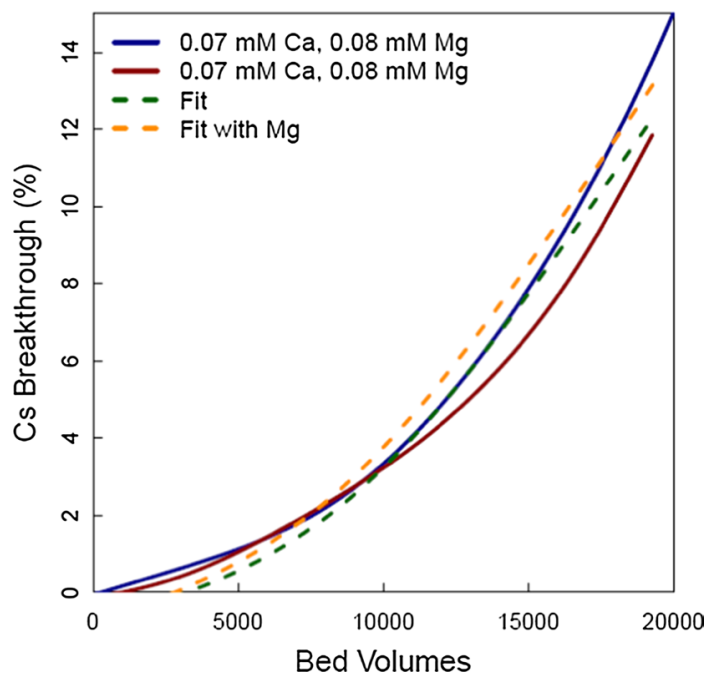

Fig. $12 \mathrm{Cs}^{+}$ion exchange model fit with $\left[\mathrm{Mg}^{2+}\right]=0.08 \mathrm{mM}(2 \mathrm{ppm})$

All transport models are to some extent semi-empirical, and the model described here is a simplified description of a complex system. However, it has been used successfully for over a decade to predict the performance of the ion exchange columns in SIXEP, and so it is effective as a model for plant support purposes. The sensitivity of the model to feed flow rates and ion concentrations has also recently been evaluated using Artificial Neural Networks [U. Oparaji et al./Neural Networks 96 (2017) 80-90].

\section{Conclusions}

The column experiments have shown that clinoptilolite can be effective in removing $\mathrm{Cs}^{+}$and $\mathrm{Sr}^{2+}$ ions from aqueous solutions that are simulants of the feed to the SIXEP plant. Although $\mathrm{Ca}^{2+}, \mathrm{Mg}^{2+}, \mathrm{K}^{+}$and $\mathrm{Na}^{+}$have all been shown to compete with $\mathrm{Cs}^{+}$and $\mathrm{Sr}^{2+}$, at the concentrations in the SIXEP feed solutions, the performance was sufficient to control $\mathrm{Cs}^{+}$and $\mathrm{Sr}^{2+}$ concentrations in the effluents. Higher concentrations of these competing ions could result in reduced removal of $\mathrm{Cs}^{+}$and $\mathrm{Sr}^{2+}$, and consequently more frequent changing of the ion exchange beds. For $\mathrm{Ca}^{2+}, \mathrm{Mg}^{2+}$ and $\mathrm{K}^{+}$, concentrations much less than $1 \mathrm{mM}$ were sufficient to reduce performance significantly, and so it is important to control the concentrations of these species in the SIXEP feed solutions carefully. The clinoptilolite has a low selectivity for $\mathrm{Na}$ ions, and concentrations of several millimolar are required to influence performance, although there is a high background concentration of $\mathrm{Na}^{+}$in the feed solutions. One suggested method for the control of $\mathrm{Ca}^{2+}$ and $\mathrm{Mg}^{2+}$ is an increase in solution $\mathrm{pH}$, via the addition of Na hydroxide. Although the associated reduction in the solubility of the
Group II ions would benefit the performance, the increase in $\mathrm{Na}^{+}$concentration would have the opposite effect, and so there will be an optimum $\mathrm{pH}$ for performance, which is likely to be different for $\mathrm{Cs}^{+}$and $\mathrm{Sr}^{2+}$.

The experiments have shown that there is very significant variation in clinoptilolite performance from sample to sample, even from the same formation. The SIXEP plant has been operating for 3 decades, and has succeeded in reducing the discharges of ${ }^{134 / 137} \mathrm{Cs}$ and ${ }^{89 / 90} \mathrm{Sr}$ to the Irish Sea during that time. Although the performance of the clinoptilolite is variable, even within a small subsection of a single mine, by monitoring of the effluent from the plant, it is possible to control the discharges.

The model described in this paper can simulate the behaviour of the clinoptilolite in laboratory column experiments. It has also been applied to the performance of the plant itself, and it can also successfully simulate its performance. The good performance of the clinoptilolite in removing $\mathrm{Sr}^{2+}$ from solution in the laboratory and on plant was somewhat surprising, given the zeolite $\mathrm{Si} / \mathrm{Al}$ ratio. It seems that the formation of metal bicarbonate ions of the divalent Group II ions may play an important role in the success of the ion exchange process, although more work would be required to demonstrate that conclusively.

This work shows that a combination of laboratory scale experiments and coupled chemical transport modelling can be used to design and optimise the performance of a successful nuclear effluent treatment plant. As the feed solutions to the plant change during the decommissioning and remediation of the Sellafield site, the understanding of the mechanisms and processes controlling the behaviour of radioisotopes reported here will play an important role in maintaining low discharge rates in the future.

Acknowledgements The authors would like to thank Sellafield Limited and its predecessor organisations for funding this work.

Open Access This article is distributed under the terms of the Creative Commons Attribution 4.0 International License (http://creativeco mmons.org/licenses/by/4.0/), which permits unrestricted use, distribution, and reproduction in any medium, provided you give appropriate credit to the original author(s) and the source, provide a link to the Creative Commons license, and indicate if changes were made.

\section{References}

1. Marinin DV, Brown GN (2000) Studies of sorbent/ion-exchange materials for the removal of radioactive strontium from liquid radioactive waste and high hardness groundwaters. Waste Manag 20:545-553

2. Howden M, Pilot J (1984) Ion exchange technology. In: Naden D, Streat M (eds). Ellis Horwood, London

3. Ames LL (1960) Cation sieve properties of clinoptilolite. Am Miner 45:689-700 
4. Behrens EA, Sylvester P, Clearfield A (1998) Assessment of a sodium nonatitanate and pharmacosiderite-type ion exchangers for strontium and cesium removal from DOE waste simulants. Environ Sci Technol 32:101-107

5. Dyer A (2007) Introduction to zeolite science and practice. In: Cejka J, van Bekkum H, Corma A, Schuth F (eds) 3rd revised ed. Elsevier, Amsterdam

6. Smyth JR, Spaid AT, Bish DL (1990) Crystal structures of a natural and a Cs-exchanged clinoptilolite. Am Miner 75:522-528

7. Dyer A, Mikhail KY (1985) The use of zeolites for the treatment of radioactive waste. Miner Mag 9:203-210

8. Ames LL (1962) Characterization of a strontium-selective zeolite. Am Miner 47:1317-1326

9. Keheyan Y, Khachatryan S, Christidis G, Moraetis D, Gevorkyan R, Sarkisyan H, Yeritsyan H, Nikoghosyan S, Sahakyan A, Kekelidze N, Akhalbedashvili L (2005) Sorption behavior of tritiated water on Armenian natural zeolites. J Radioanal Nucl Chem Lett 264:671-677

10. Nikashina VA, Serova IB, Kats EM, Tikhonov NA, Tokmachev MG, Novgorodov PG (2011) Mathematical modelling of the sorption dynamics of radionuclides by natural clinoptilolite in permeable reactive barriers. Clay Miner 46:233-240

11. Seneca SM, Rabideau AJ (2013) Natural zeolite permeable treatment wall for removing Sr-90 from groundwater. Environ Sci Technol 47:1550-1556

12. Valcke E, Engels B, Cremers A (1997) The use of zeolites as amendments in radiocaesium- and radiostrontium-contaminated soils: a soil-chemical approach. Part I: Cs-K exchange in clinoptilolite and mordenite. Zeolites 18:205-211

13. Valcke E, Engels B, Cremers A (1997) The use of zeolites as amendments in radiocaesium- and radiostrontium-contaminated soils: a soil-chemical approach. Part II: Sr-Ca exchange in clinoptilolite, mordenite, and zeolite A. Zeolites 18:212-217

14. Dyer A (2000) Environmental mineralogy: microbial interactions, anthropogenic influences, contaminated land and waste management. In: Cotter-Howells JD, Campbell LS, Valsami-Jones E, Batchelder M (eds). Min Soc GB Ireland, London

15. Palmer JL, Gunter ME (2001) The effects of time, temperature, and concentration on $\mathrm{Sr}^{2+}$ exchange in clinoptilolite in aqueous solutions. Am Miner 86:431-437

16. Cortés-Martínez R, Olguín MT, Solache-Ríos M (2010) Cesium sorption by clinoptilolite-rich tuffs in batch and fixed-bed systems. Desal 258:164-170

17. Um W, Papelis C (2003) Sorption mechanisms of $\mathrm{Sr}$ and $\mathrm{Pb}$ on zeolitized tuffs from the Nevada test site as a function of $\mathrm{pH}$ and ionic strength. Am Miner 88:2028-2039

18. O'Day PA, Newville M, Neuhoff PS, Sahai N, Carroll SA (2000) X-ray absorption spectroscopy of strontium (II) coordination: I. Static and thermal disorder in crystalline, hydrated, and precipitated solids and in aqueous solution. J Colloid Interface Sci 222:184-197

19. Bogdanova VI, Belitsky IA, Fursenko BA, Prodeina LM, Galai GI, Drobot IV (2000) Natural zeolites for the third millennium. In: Collela C, Mumpton FA (eds). De Fede Editore, Napoli

20. Parry SA, O’Brien L, Fellerman AS, Eaves CJ, Milestone NB, Bryan ND, Livens FR (2011) Plutonium behaviour in nuclear fuel storage pond effluents. Energy Environ Sci 4:1457-1464

21. Gregson CR, Goddard DT, Sarsfield MJ, Taylor RJ (2011) Combined electron microscopy and vibrational spectroscopy study of corroded Magnox sludge from a legacy spent nuclear fuel storage pond. J Nucl Mater 412:145-156

22. Vaughan DEW (1978) Natural zeolites, occurrence, properties, uses. In: Sands LD, Mumpton FA (eds). Pergamon Press, Oxford

23. Eisenman G (1962) Cation selective glass electrodes and their mode of operation. Emer Tech Biophys 2:259-323

24. Zhao D, Cleare K, Oliver C, Ingram C, Cook D, Szostak R, Kevan L (1998) Characteristics of the synthetic heulandite-clinoptilolite family of zeolites. Microporous Mesoporous Mater 21:371-379

25. Dyer A, Newton JA, O'Brien L, Owens S (2009) Studies on a synthetic sitinakite-type silicotitanate cation exchanger. Part 2. Effect of alkaline earth and alkali metals on the uptake of Cs and Sr radioisotopes. Microporous Mesoporous Mater 120:272-277

26. Dyer A, Newton JA, Pillinger M (2010) Synthesis and characterisation of mesoporous silica phases containing heteroatoms, and their cation exchange properties. Part 3. Measurement of distribution coefficients for uptake of 137-Cs, 89-Sr and 57-Co radioisotopes. Microporous Mesoporous Mater 130:56-62

27. Ames LL (1962) Effect of base cation on the cesium kinetics of clinoptilolite. Am Miner 47:1310-1316

28. Shahwan T, Akar D, Eroglu AE (2005) Physicochemical characterization of the retardation of aqueous $\mathrm{Cs}^{+}$ions by natural kaolinite and clinoptilolite minerals. J Colloid Interface Sci 285:9-17

29. Faghihian H, Marageh MG, Kazemian H (1999) The use of clinoptilolite and its sodium form for removal of radioactive cesium, and strontium from nuclear wastewater and $\mathrm{Pb}^{2+}, \mathrm{Ni}^{2+}, \mathrm{Cd}^{2+}, \mathrm{Ba}^{2+}$ from municipal wastewater. App Radiat Isot 50:655-660

30. Woods RM, Gunter ME (2001) Na-and Cs-exchange in a clinoptilolite-rich rock: analysis of the outgoing cations in solution. Am Miner 86:424-430

31. Ames LL (1962) Characterization of a strontium-selective zeolite. Am Miner 47:1317-1326

32. Abusafa A, Yucel H (2002) Removal of ${ }^{137} \mathrm{Cs}$ from aqueous solutions using different cationic forms of a natural zeolite: clinoptilolite. Sep Purif Technol 28:103-116

33. Pabalan RT, Bertetti FP (1999) Experimental and modeling study of ion exchange between aqueous solutions and the zeolite mineral clinoptilolite. J Solut Chem 28:367-393

34. Yin J, Jeen SW, Lee DR, Mayer KU (2014) Reactive transport modeling of ${ }^{90} \mathrm{Sr}$ sorption in reactive sandpacks. J Hazard Mater 280:685-695

35. Crank J (1975) The mathematics of diffusion, 2nd edn. Clarendon Press, Oxford

36. Parkhurst DL, Appelo CAJ (1999) User's guide to PHREEQC (version 2) a computer program for speciation, batch-reaction, one-dimensional transport and inverse geochemical calculations, U.S. Geological Survey, Water Resources Investigations Report 99-4259 wwwbrr.cr.usgs.gov/projects/GWC_coupled/phreeqc

37. Fondeur FF, Hang T, Walker DD, Wilmarth WR, Fink SD (2003) The effect of carbonate, oxalate, and peroxide on the cesium loading of Ionsiv ${ }^{\circledR}$ Ie-910 and Ie-911. Sep Sci Technol 38:3175-3188

38. Elizondo NV, Ballesteros E, Kharisov BI (2000) Cleaning of liquid radioactive wastes using natural zeolites. Appl Radiat Isot 52:27-30

39. Smičiklas I, Dimović S, Plećaš I (2007) Removal of $\mathrm{Cs}^{1+}, \mathrm{Sr}^{2+}$ and $\mathrm{Co}^{2+}$ from aqueous solutions by adsorption on natural clinoptilolite. Appl Clay Sci 35:139-144 